\title{
Vulvovaginal photodynamic therapy in genital erosive lichen planus
}

\author{
Anne Lise Ording Helgesen \\ Norwegian National Advisory Unit on Women's Health \\ Institute of Clinical Medicine, University of Oslo \\ Department of Dermatology, Oslo University Hospital
}

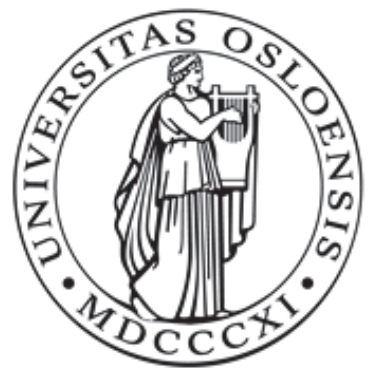

Doctoral thesis 
(c) Anne Lise Ording Helgesen, 2016

Series of dissertations submitted to the Faculty of Medicine, University of Oslo

ISBN 978-82-8333-265-0

All rights reserved. No part of this publication may be reproduced or transmitted, in any form or by any means, without permission.

Cover: Hanne Baadsgaard Utigard

Printed in Norway: 07 Media AS - www.07.no 


\section{TABLE OF CONTENTS}

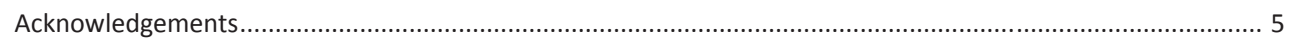

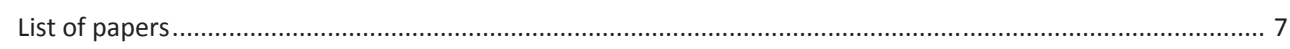

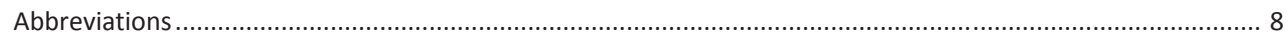

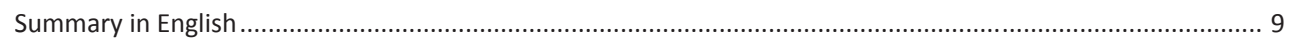

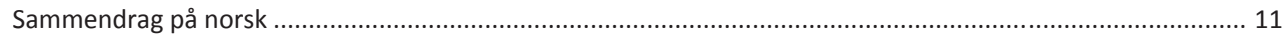

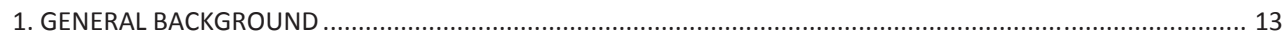

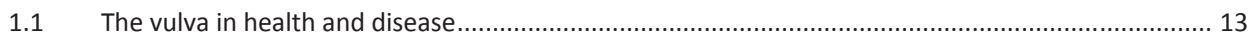

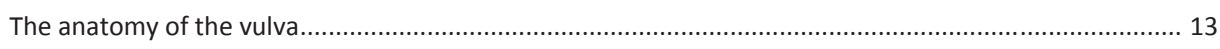

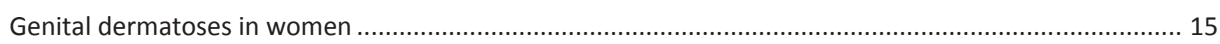

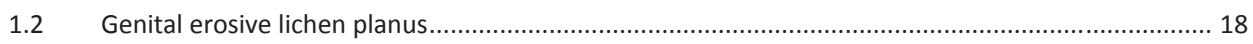

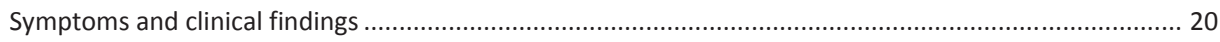

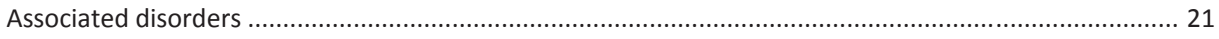

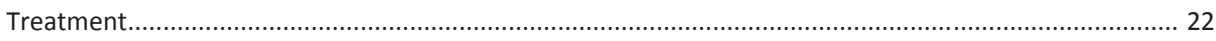

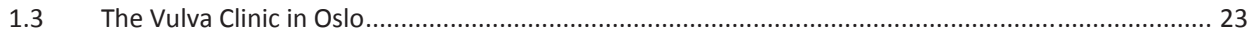

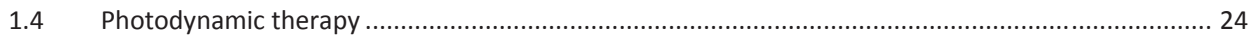

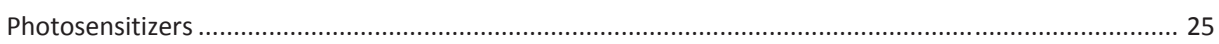

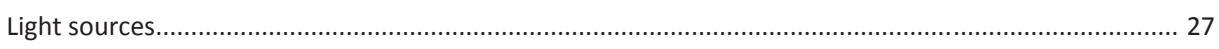

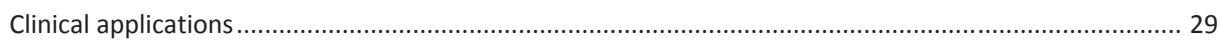

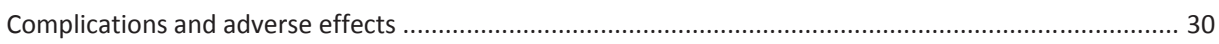

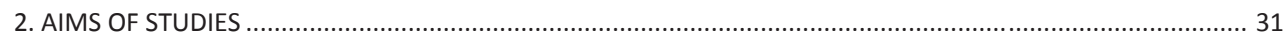

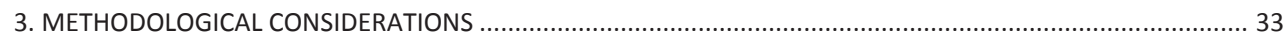

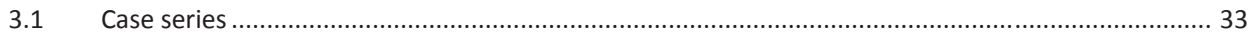

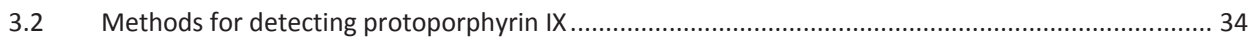

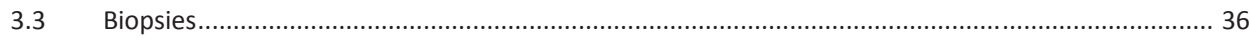

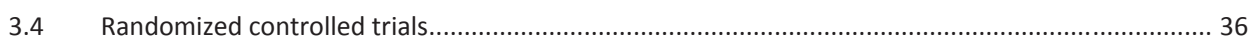

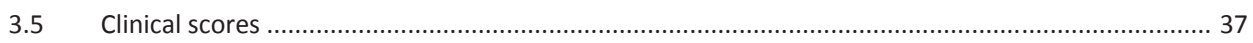

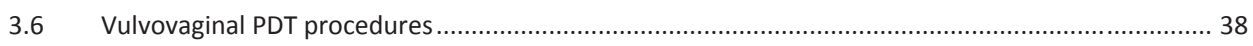

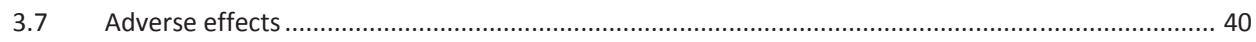

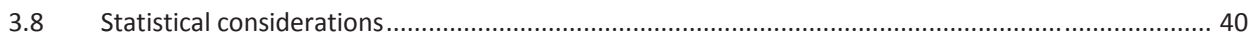

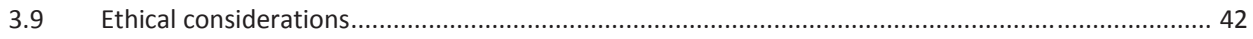

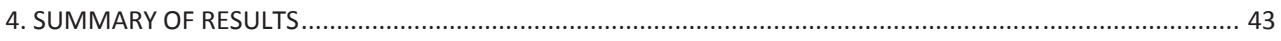

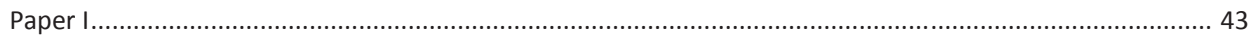

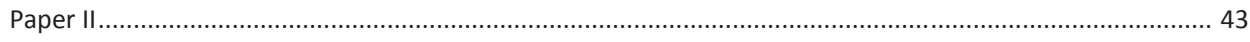

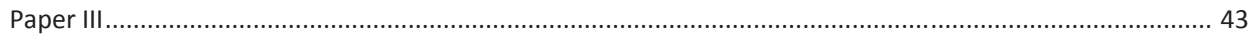




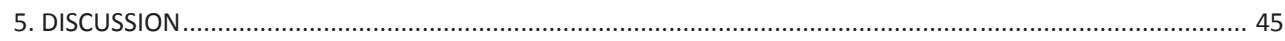

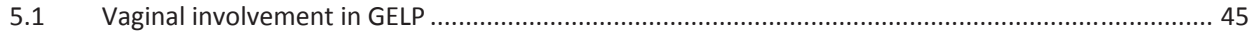

5.2 HAL dosage, application time and PpIX biodistribution .......................................................... 46

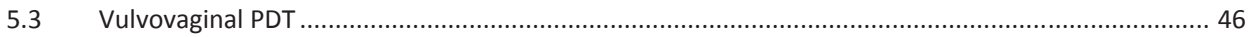

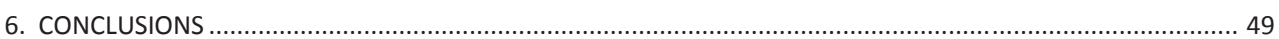

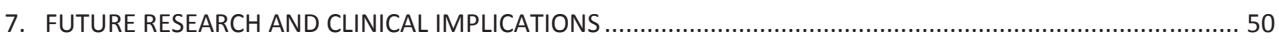

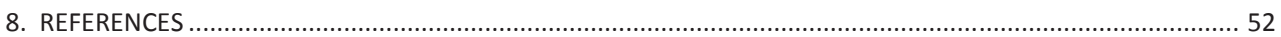

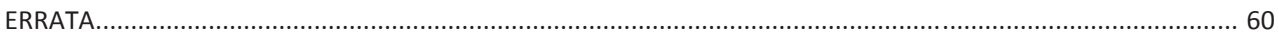

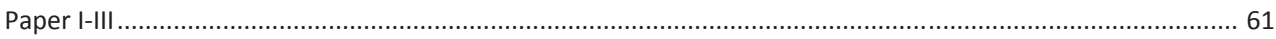




\section{ACKNOWLEDGEMENTS}

The studies on which this thesis is based, were carried out during my time as a research fellow at the Norwegian National Advisory Unit on Women's Health, Oslo University Hospital, and as a Ph.D. student at the Institute of Clinical Medicine, University in Oslo in the period 2009-16. Office space was provided by the Department of Dermatology, Oslo University Hospital.

I would like to express my gratitude to everyone who has supported me in different ways and contributed to this thesis. In particular, I would like to thank:

- The women who never hesitated to participate in the studies, regardless of your genital pain and often long travel distance.

- Tom Tanbo, who believed in my ideas of exploring a new treatment for women with genital erosive lichen planus and hired me as a research fellow. As cosupervisor, you used your exceptional experience to enhance my scientific thinking.

- Trond Warloe, my first supervisor, for your continuous friendly attitude and genuine support. You know the history of photodynamic therapy and are a practical genius in physics and technical details, from which I have learned a lot. This thesis would not have been possible without your knowledge and support.

- Petter Gjersvik, for your professional contribution to study design, interpretation and manuscript writing. Your meticulous corrections and attention to details have shown me the way to scientific writing. Thanks for being an available and enthusiastic supervisor.

- Siri Vangen, at The Norwegian National Advisory Unit Centre on Women's Health, for providing strong financial support, and to Pernille Frese for all your invaluable technical and practical support.

I also thank my co-authors for your valuable contributions:

- Rolf Kirschner, my friend and colleague, who still gives me support and advice regarding gynaecology. Your great integrity and fighting spirit have contributed to 
the establishment of the Vulva Clinic at Oslo University Hospital as a reference centre for all health regions in Norway.

- Are Hugo Pripp, for the highly appreciated statistical support and constant willingness to explain over and over again.

- Qian Peng, for inspiring me with creative suggestions and for sharing your great knowledge about photosensitizers.

- Vlada Vasovic, for technical assistance with the biopsies.

- Peter Jebsen, for willingly analysing the histopathological specimen.

Many thanks to all my supportive colleagues, friends and family:

- The out-patient clinic staff at Department of Obstetrics and Gynaecology, Oslo University Hospital, especially Tone Walstad for organizing patient-flow and follow-ups.

- Nurses, secretaries and the anaesthesiology team at the Day-care unit, Department of Obstetrics and Gynaecology, Ullevål Hospital, for support and willingness to assist during the photodynamic treatment sessions.

- All my colleagues at the Department of Dermatology, Oslo University Hospital, especially Ingrid Roscher, Kristine Bø and Teresa Løvold Berents, who gladly shared your desks and office and continuously supported me with fun, laughter and determination in times of chaos and difficulty.

- The leadership of the Department of Dermatology, Oslo University Hospital, for your support.

Last, but not least, I thank my love, Tom, who a late spring evening convinced me to enter the world of research and made me believe in myself. Thank you for your outstanding support and priceless advises.

Oslo, February 2016

Anne Lise Ording Helgesen 


\section{LIST OF PAPERS}

\section{Paper I:}

Helgesen AL, Gjersvik P, Jebsen P, Kirschner R, Tanbo T. Vaginal involvement in genital erosive lichen planus.

Acta Obstetrica Gynecologica Scandinavica 2010; 89: 966-70.

\section{Paper II:}

Helgesen AL, Gjersvik P, Peng Q, Vasovic V, Pripp AH, Jebsen P, Tanbo T, Warloe T. Biodistribution of protoporphyrin IX in female genital erosive lichen planus after topical application of hexaminolevulinate.

Photodiagnosis and Photodynamic Therapy 2014; 11: 113-7.

\section{Paper III:}

Helgesen ALO, Warloe T, Pripp AH, Kirschner R, Peng Q, Tanbo T, Gjersvik P. Vulvovaginal photodynamic therapy vs. topical corticosteroids in genital erosive lichen planus: a randomized controlled trial.

British Journal of Dermatology 2015; 173: 1156-62. 


\section{Abbreviations}

$\begin{array}{ll}\text { ALA } & \text { 5-aminolevulinic acid } \\ \text { AUC } & \text { Area under the curve } \\ \text { BCC } & \text { Basal cell carcinoma } \\ \text { CIN } & \text { Cervical intraepithelial neoplasia } \\ \text { ECSVD } & \text { European College for the Study of Vulval Disease } \\ \text { GELP } & \text { Genital erosive lichen planus } \\ \text { HAL } & \text { Hexyl 5-aminolevulinic acid } \\ \text { HCV } & \text { Hepatitis C-virus } \\ \text { HPV } & \text { Human papilloma virus } \\ \text { ISSVD } & \text { International Society for the Study of Vulvar Disease } \\ \text { LED } & \text { Light emitted diodes } \\ \text { MAL } & \text { Methyl 5-aminolevulinic acid } \\ \text { OUS } & \text { Oslo University Hospital } \\ \text { PDT } & \text { Photodynamic therapy } \\ \text { PpIX } & \text { Protoporphyrine IX } \\ \text { RCT } & \text { Randomized controlled trial } \\ \text { SCC } & \text { Squamous cell carcinoma } \\ \text { SD } & \text { Standard deviation } \\ \text { VAS } & \text { Visual analogue scale } \\ \text { VIN } & \text { Vulval intraepithelial neoplasia }\end{array}$




\section{SUMMARY IN ENGLISH}

Genital erosive lichen planus (GELP) is a chronic inflammatory skin disease characterized by painful vulval and vaginal erosions and limited treatment options. Topical photodynamic therapy (PDT) is increasingly used in premalignant and malignant diseases and may also have an effect in inflammatory disease.

The aims of the studies were to describe the clinical and histopathological characteristics of GELP in women diagnosed at a specialized vulva clinic, with special emphasis on vaginal involvement and sexual function, and to conduct a randomized controlled trial (RCT) in women with GELP, comparing one session vulvovaginal PDT with daily application of topical corticosteroids for six weeks. Prior to the RCT, we performed a study on the biodistribution of protoporphyrin IX (PpIX) after topical application of hexyl 5-aminolevulinate (HAL) gel on genital mucosal surfaces in order to determine an adequate dosage and application time of HAL to be used in the RCT study.

Vaginal involvement was seen in 49 out of 58 women with GELP. Information about sexual function was reported by 51 women, of whom 46 reported sexual abstinence or dyspareunia (Paper I). Application of $2 \mathrm{ml} \mathrm{HAL} 6.25 \mathrm{mg} / \mathrm{ml}$ for 3 hours was found to be adequate for absorption and conversion to PpIX in submucosal inflammatory cells, characteristic for GELP, and giving no systemic absorption (Paper II). In the RCT, 40 women with GELP were randomized to either one session with HAL-PDT $(n=20)$ or daily application of topical corticosteroids for six weeks $(n=20)$. Three patients in the corticosteroid group withdrew after 1-3 weeks. At week 6 and 24 , we were not able to demonstrate any significant differences in the reduction of clinical and symptomatic scores between those treated with PDT and those treated with topical corticosteroids, the former group reporting significantly less use of topical corticosteroids in weeks 7-24. Some pain and discomfort during PDT occurred, but adverse effects were few and mild (Paper III).

In conclusion, vaginal involvement in GELP seems to be more frequent than described in other studies. Vulvovaginal PDT, using HAL as photosensitizer, seems to be a feasible, effective and safe treatment in women with GELP. 


\section{SAMMENDRAG PÅ NORSK}

Genital erosiv lichen planus (GELP) er en kronisk, inflammatorisk hudsykdom preget av smertefulle erosjoner i vulva og vagina og med få behandlingsmuligheter. Topikal fotodynamisk behandling (PDT) brukes i økende grad ved premaligne og maligne hudsykdommer og kan også ha en effekt ved inflammatorisk sykdom.

Målsetningen for våre studier var å beskrive karakteristiske kliniske og histopatologiske funn ved GELP hos kvinner diagnostisert ved en spesialisert vulvaklinikk, med spesiell vekt på vaginale forandringer og seksuell funksjon, og å gjennomføre en randomisert kontrollert behandlingsstudie (RCT) hos kvinner med GELP der effekten av én behandling med vulvovaginal PDT ble sammenliknet med daglig bruk av topikale kortikosteroider i 6 uker. Vi gjennomførte først en biodistribusjonsstudie av protoporfyrin IX (PpIX) etter applikasjon av hexyl 5aminolevulinat (HAL) gel på genitale slimhinneoverflater for å bestemme adekvat dosering og applikasjonsstid for HAL i behandlingsstudien.

Vaginale GELP-forandringer ble påvist hos 49 av 58 kvinner med GELP. Seksuell funksjon ble rapportert av 51 kvinner, hvorav 46 var seksuelt avholdne eller hadde dyspareuni. Applikasjon av $2 \mathrm{ml} \mathrm{HAL} \mathrm{6,25} \mathrm{mg/ml} \mathrm{i} 3$ timer ble funnet å være adekvat for absorpsjon og konvertering til PpIX i submukøsee inflammatoriske celler, som er karakteristisk for GELP, uten tegn på systemisk absorpsjon. I

behandlingsstudien ble 40 kvinner med GELP randomisert til enten én behandling med HAL-PDT $(n=20)$ eller daglig bruk av topikale kortikosteroider i 6 uker $(n=20)$. Tre pasienter i kortikosteroid-gruppen trakk seg etter 1-3 uker. I uke 6 og 24 var vi ikke i stand til å vise noen signifikante forskjeller i reduksjon av kliniske skår eller symptomskår mellom dem som ble behandlet med PDT, og dem som ble behandlet med topikale kortikosteroider. Den førstnevnte gruppen rapporterte signifikant mindre bruk av topikale kortikosteroider i uke 7-24. Noen pasienter hadde smerte og ubehag under PDT, men bivirkningene var få og milde.

Konklusjon: Vaginal GELP synes å være hyppigere enn beskrevet $\mathrm{i}$ andre studier. Vulvovaginal PDT med bruk av HAL som fotosensibilisator synes å være en gjennomførbar, effektiv og trygg behandling hos kvinner med GELP. 


\section{GENERAL BACKGROUND}

\subsection{THE VULVA IN HEALTH AND DISEASE}

The vulva (from the Latin word vulva, probably from the verb volvere, meaning to turn $)^{1}$ has been described as a mysterious organ, surrounded by myths and superstition ${ }^{2}$. The cultural image of the female external genital organs has throughout history been shaped by religion, politics and arts, and some cultures have tended to view the vulva as something shameful that should be hidden.

In the medical literature, vulva has been described as "the forgotten pelvic organ", receiving little attention, and vulval diseases as a hidden health problem being largely ignored ${ }^{3}$. Only recently, the medical scientific community has begun to show interest in the structure and function of the female external genitalia and the dynamic role of the vulva in reproduction, in sexual health and for the quality of life in women.

\section{THE ANATOMY OF THE VULVA}

The vulva is the term describing the external part of the female genital organ, located between mons pubis, anus and the genitocrural fold (Fig 1).

The vulva is rich in nerves that are stimulated during sexual activity and sexual arousal. The vulva also contains the opening of the female urethra, and thus serves the vital function of passing urine ${ }^{4}$. Anatomical variations of the vulva, hormonal status and age, are important in order to understand and recognize the wide range of vulval disorders. 


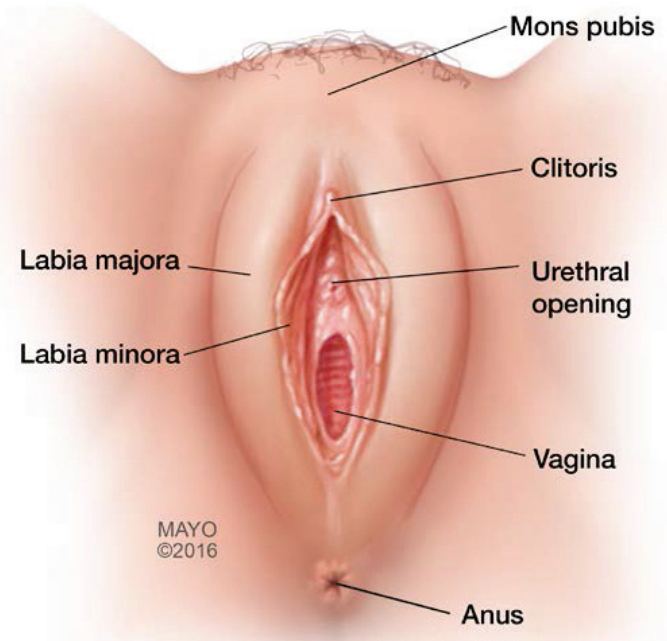

FIGURE 1. ANATOMY OF THE VULVA. BY PERMISSION OF MAYO FOUNDATION FOR MEDICAL EDUCATION AND RESEARCH. ALL RIGHTS RESERVED.

The main anatomical components of the vulva are the labia majora, the labia minora, the clitoris, the vestibulum, the urethral meatus, the hymen, the vestibular glands and the Bartholin's glands. The hymenal ring constitutes the border between the vulva and the vagina.

The soft mound at the front of the vulva, the mons pubis, is formed by fatty tissue covering the pubic bone, and becomes covered with hair during puberty. Mons pubis separates into two folds of skin called the labia majora. They are made up of folds of adipose and fibrous tissue and are covered with hair, protecting the other external genital organs. During sexual stimulation, the labia majora may become swollen due to increased blood flow. The labia minora are two thinner folds located medial to the labia majora. They contain mainly connective tissue and blood vessels, and have abundant sebaceous glands on the lateral side. The labia minora covers the vaginal and urethral opening. The fold between the labia majora and labia minora is called the interlabial sulcus. The clitoris is located at the anterior part of the vulval vestibule and corresponds to the male penis. The perineum is the anatomical area between the introitus of the vagina and the anus. 
The Hart's line is the junction between the squamous epithelium of the labia minora and the transitorial epithelium of the vestibulum. The vulval vestibulum is the mucosal part of the vulva, covered by non-keratinized transitional epithelium. It is located between the Hart's line and the hymenal ring. Various glands and the urethral meatus are located within this area. Beside the clitoris, this is the most sensitive part of the vulva. The hymen is separating the vestibule from the vagina as a remnant of connective tissue membrane. After sexual intercourse and childbirth, the shape will change and the membrane often disappears.

Different vestibular glands are located in the vestibulum. The Skene's glands are located para-urethral, while the minor vestibular glands and the two major Bartholin's glands are located within the vestibulum with varying position of the duct openings. The glands produce a thick fluid, which acts as lubricant during sexual intercourse.

The vagina is a fibromuscular elastic tube of approximately $7.5 \mathrm{~cm}$ that extends from the vestibulum to the cervix. The vagina runs obliquely upward and backward and is positioned between the urethra and rectum. Urethra is anteriorly positioned, while rectum is posteriorly positioned to the vagina. Non-keratinized stratified squamous epithelium covers a thin loose connective layer with many elastin fibers, called the lamina propria, which allows the vagina to stretch. During estrogen stimulation the epithelium becomes folded ${ }^{5}$. A layer of smooth muscle tissue located deep to the lamina propria makes the vagina expand and contract during sexual intercourse and childbirth. Watery secretions, produced by the vaginal epithelium, lubricate the vagina. Having an acidic $\mathrm{pH}$ between 3.5 and 4.5 , they also prevent the growth of bacteria and yeast. Several factors, including estrogens and sexual stimulation, will increase the vaginal fluid production ${ }^{6,7}$.

\section{GenitAL DERMATOSES IN WOMEN}

Symptoms like pruritus, irritation and pain, associated with vulval dermatoses, are common in women, although the true prevalence is unknown ${ }^{8}$. Numerous nonmalignant skin diseases may involve the vulva. Genital dermatoses may present in a variety of ways, ranging from asymptomatic to chronic disabling conditions that may be difficult to treat, and that may have severe impact on the woman's quality of life ${ }^{9}$. 
The most common vulval dermatoses are irritant and allergic contact dermatitis, lichen simplex chronicus, psoriasis, lichen sclerosus, lichen planus and plasma cell vulvitis.

Contact dermatitis is a frequent vulval problem following exposure to exogenous irritants or allergens. It can present in acute, subacute or chronic forms, and is reported to be one of the most common dermatoses in clinical practice ${ }^{10}$. Irritant contact dermatitis is the most common form of contact dermatitis ${ }^{11}$. The condition occurs following exposure to exogenous irritant substances, while allergic contact dermatitis is a type IV, delayed hypersensitivity reaction. As women increasingly apply various products on the vulva, the prevalence of vulval contact dermatitis seems to be increasing. Typical contact dermatitis-inducing products are soaps, menstrual pads, toilet paper, feminine sprays, condoms and spermicides. Women with contact dermatitis typically present with burning, itching and dyspareunia, with erythema, fissures, oedema and vulval erosions ${ }^{9}$. A thorough case history and a complete physical examination are often needed to diagnose and address the problem properly. Patch testing is often necessary to make the right diagnosis.

Lichen simplex chronicus is an eczematous disorder characterized by chronic itching, scratching and lichenification. It may be idiopathic or seen as the end stage of a long-standing pruritic disorder, such as contact dermatitis, candidiasis or lichen sclerosus $^{12}$. The vulva may become variable pigmented, oedematous and excoriated, with fissures and superinfection. Histopathological examination will show a chronic dermal inflammatory infiltrate, hyperkeratosis, spongiosis and acanthosis ${ }^{13}$.

Psoriasis in the vulva may occur as an isolated finding, but is often also involving rima internates and the axillar area as a part of inverse psoriasis. The diagnosis is made clinically, based on a family history of psoriasis and typical psoriatic lesions on elbows, knees, scalp, nails and/or elsewhere. Unlike psoriasis on other parts of the body, itching and irritation are often present. The location is mostly at the hairy part of the pubes area and around the anus, involving rima internates, but not the genital mucosa. Typical psoriatic scaling is mostly not seen ${ }^{14}$.

Lichen sclerosus is a chronic autoimmune disorder, mainly seen in menopausal women, but may also affect young girls ${ }^{15}$. Typical symptoms are intense pruritus or less often chronic pain, although some patients are asymptomatic. The typical clinical findings include white atrophic plaques, depigmentation, small 
erosions and pitch-point haemorrhage. Scarring may lead to labial adhesions, narrowing of the introitus and loss of normal vulval architecture ${ }^{9}$. Lichen sclerosus may be difficult to distinguish from genital erosive lichen planus, but lichen sclerosus will most often present with white atrophic symmetrical lesions and tends to be more pruritic. Vaginal involvement is rare. Histopathological changes are characteristic with epidermal thinning, loss of rete pigs, hydrop degeneration of the basal cell layer, dermal fibrosis and a dermal inflammatory cell infiltrate ${ }^{16}$. Lichen sclerosus in women is associated with other auto-immune disorders, such as thyroid disease, alopecia areata and vitiligo ${ }^{17-19}$. Some authors report a 3-7\% risk of developing vulval carcinoma ${ }^{20-22}$.

Lichen planus is an inflammatory, autoimmune, mucocutaneous disease with multiple clinical variants. It may involve the skin, hair, nails and mucosa. In the genital area, lichen planus can be papulosquamous, hypertrophic or erosive ${ }^{23}$. Papulosquamous lichen planus affects the cutaneous, non-mucosal part of vulva, and the hypertrophic lichen planus affects the perineum and the perianal area. Genital erosive lichen planus (GELP) is the most common form of genital lichen planus and is characterized by sore or painful erosions involving the labia minora and vestibulum and often extending into the vagina.

Plasma cell vulvitis, also called Zoons vulvitis, is an inflammatory disease of the vulva, in some cases also involving the vagina as plasma cell vaginitis. This disease occurs mostly in adults and tends to be chronic. The typical erythematous lesions have a red brown colour and a sharp border. Symptoms include burning and pain, more seldom itch. Typical histological findings are a high number of plasma cell infiltrates in the submucosa ${ }^{24}$.

Several other vulvovaginal dermatoses are less common: Graft-versus-host disease (GVHD) may develop in the genital region and may resemble GELP. Stem cell transplant patients may develop genital GVHD with vaginal stenosis and scarring ${ }^{25}$. Most cases of vaginal GVHD occur within two years after stem cell transplantation ${ }^{26,27}$.

Bullous disorders, such as mucous membrane pemphigoid, pemphigus vulgaris and linear IgA dermatosis may present with similar clinical picture in the vulva and the vagina. Direct immunofluorescence is helpful to differentiate between these conditions and GELP. Bullous disorders also tend to involve other areas of the skin or mucosa. Lupus erythematosus may involve the genital area and can be 
distinguished from lichen planus by direct immunofluorescence ${ }^{28}$. Vulval intraepithelial neoplasia (VIN) tends to occur unilateral and expand continuously and will not heal after treatment. A histological analysis is essential for this diagnosis. Behçet's disease, Crohn's disease and infective ulcerations usually cause localized and more discrete ulcerations rather than generalized chronic inflammation, as in $G E L P^{23}$. These lesions also tend to come and go more intermittently. Behçet's disease often causes recurrent oral and ocular involvement, which are major criteria for the diagnosis. Vulvar manifestations in Crohn's disease may precede the bowel involvement by many years.

Desquamative inflammatory vaginitis (DIV) causes the triad of dyspareunia, purulent inflammatory vaginitis and increased vaginal discharge. In addition to a vaginal high $\mathrm{pH}$, the characteristic findings are microscopic high number of leucocytes and immature squamous epithelial cells. Lactobacillus is absent ${ }^{29}$. This sterile inflammatory vaginitis is often difficult to treat. Because of the clinical findings, including severe vaginal inflammation and discharge, it remains unclear if DIV is a distinct separate entity or a subtype of GELP ${ }^{30,31}$.

Other inflammatory diseases that may involve the vulva and the vagina include bartholinitis, hidroadenitis suppurativa, ulcus vulvae acutum and aphtosis vulvae.

Vulvodynia is a long-lasting disorder, often presented as localized provoked vulvodynia and dyspareunia in young women. The pathogenesis is unknown, but patients may have mucosal nerve fibre proliferation and enhanced systemic pain perception caused by an inflammatory response to trauma, and a dysfunction in the pelvic floor muscles ${ }^{32}$.

\subsection{Genital erosive lichen planus}

As previously described, GELP is a mucosal variant of lichen planus, which is an inflammatory, autoimmune, mucocutaneous disease with multiple clinical variants involving the skin, hair, nails and/or mucosa. Lichen planus is most common in middle-aged persons with a slight predominance in women ${ }^{33}$. Lichen planus in childhood is rare ${ }^{34}$. While the cutaneous form of lichen planus usually subsides within some years, mucosal lesions tend to be more persistent, running a chronic course marked by exacerbation, slow healing and scarring ${ }^{35-37}$. The prevalence of lichen planus is unknown, but reported to be about $1 \%{ }^{38} 39$. The oral mucosa is most 
commonly involved, less often the vulvovaginal mucosa. The prevalence of the vulvovaginal type of lichen planus is uncertain as well ${ }^{40}$. In a UK case series with 37 patients with cutaneous lichen planus, vulval involvement was reported in 19 patients ${ }^{35}$. In another study of 399 women with oral lichen planus, vulvovaginal lichen planus was reported in $76^{41}$.

There are very few reports on vulval lichen planus published before 1940, partly because case reports did not distinguish between lichen sclerosus and lichen planus $^{42}$. Only in the last decades, the multifocal mucosal locations of lichen planus have been recognized and described in the oesophagus, conjunctivae, urethra, nose, larynx, stomach and anus ${ }^{41,43}$. Mucosal lichen planus affecting the vulva, vagina and gingiva has been called the vulvo-vaginal-gingival syndrome $e^{44,45}$.

The aetiology of lichen planus is unclear, although evidence suggests that it is a T-cell mediated autoimmune disorder. Many inflammatory cells are involved in this process, including T-helper cells, cytotoxic cells, natural killer cells and dendritic cells ${ }^{28,38,46}$. Increased apoptosis of keratinocytes and decreased apoptosis of $\mathrm{T}$ cells has been suggested as a possible pathogenic mechanism ${ }^{28,47}$. An autoimmune mechanism is also supported by the presence of anti-basement membrane zone antibodies in approximately $60 \%$ of patients with GELP ${ }^{48}$ and the association with other autoimmune disorders, as reported in several papers ${ }^{19,28,31}$.

Some cases of erosive lichen planus, mostly oral, have been linked to medication use or hepatitis $\mathrm{C}$ - virus $(\mathrm{HCV})$ infections ${ }^{49}$, but the reported rates of $\mathrm{HCV}$-infection differ widely, from 4 to $62 \%{ }^{50}$. How this infection may predispose patients to develop LP is unknown ${ }^{51,52}$. The geographic origin of patients seems be an important factor in HCV prevalence in patients with lichen planus, with an overrepresentation in the Mediterranean countries and Japan ${ }^{52,53}$.

The diagnosis of GELP is primarily based on the clinical presentation, but a biopsy may be helpful. Clinically, the lesions will typically have a white lacy border, called Wickham's striae, from which a biopsy should be taken to support the diagnosis. The histological examination will usually show parakeratosis or hyperkeratosis of the epidermis, basal cell degeneration and linear band-like lymphocyte infiltration in the upper dermis ${ }^{54}$. Colloid bodies, representing degenerate keratinocytes, are frequently seen in the lower epidermis and the upper dermis ${ }^{55,56}$. These specific histopathological features may not be present in mucosal lesions. Biopsies taken from erosive mucosal lesions will often be inconclusive, showing 
neither the hyperkeratosis nor the subepidermal band-like infiltrate $23,57,58$. In a UK study of 114 women with GELP, only 75 of the biopsies were diagnostic of GELP ${ }^{58}$, and in a Dutch study, only 18 out of 38 biopsies were diagnostic of GELP 59 .

\section{SYMPTOMS AND CLINICAL FINDINGS}

As mentioned previously, lichen planus in the genital area can be papulosquamous, hypertrophic or erosive ${ }^{23}$. GELP, which is the most common form of genital lichen planus, is characterized by sore or painful erosions in the labia minora, the vestibulum and/or the vagina. Frequent symptoms are pain, burning sensation, soreness, pruritus, dyspareunia and post-coital bleeding ${ }^{60}$. However, some patients may be asymptomatic or have minimal symptoms ${ }^{23}$. The vulvovaginal mucosa is often erythematous and friable, and bleeds easily on digital examination. In typical cases, the erythema is surrounded by a lacy border, the Wickham's striae, also seen in the oral lichen planus. As a majority of GELP patients also have oral involvement ${ }^{58,59}$, inspecting the oral cavity may lead to important diagnostic clues.

Extensive inflammation and erosions can result in chronic vaginal discharge, containing lymphocytes and parabasal cells. Post-inflammatory scarring may lead to considerable anatomical changes, such as absorption of the labia minora and clitorial hood, stenoses of the introitus, narrowing of the vaginal canal and total vaginal obliteration $^{58}$. As a consequence of these anatomical changes with loss of normal vulvovaginal architecture, sexual activity is often impossible ${ }^{59}$. A proper vaginal examination may also become difficult.

GELP may influence the patient's life in many ways. In one study in patients with both oral and genital lichen planus, 41 of the 49 patient reported symptoms like burning, irritation and pain, severely affecting their daily life. The patient's psychological status and quality of life may be deeply disturbed, and psychological symptoms like depression, stress and anxiety are common ${ }^{61}$.

In 2013, a diagnostic dataset was published to define the clinical or histological criteria for GELP ${ }^{62}$. According to this consensus, three out of the following nine clinical or pathological criteria were required for the diagnosis of GELP: 
1. Scarring/loss of normal architecture

2. Presence of a hyperkeratotic border to lesions, and/or Wickham's striae in surrounding skin

3. Involvement of other mucosal surfaces

4. Well-demarcated erosions or erythematous areas at the vaginal introitus

5. Symptoms of pain/burning

6. Presence of vaginal inflammation

7. Presence of a well-defined inflammatory band involving the dermo-epidermal junction

8. Inflammatory band that consists predominantly of lymphocytes

9. Signs of basal layer degeneration

There are few studies on GELP in women, and most of them are focusing on the vulval involvement. Vaginal involvement is reported to vary from 0 and up to $70 \%$ of patients with erosive lichen planus ${ }^{63,64}$ and can also be seen without any vulval involvement $^{23,64}$. In some patients that are not sexually active, vaginal synechiae may develop without any symptoms.

\section{ASSOCIATED DISORDERS}

GELP has been reported to be associated with other autoimmune diseases, such as vitiligo, alopecia areata and thyroid disease, with a prevalence of $29 \%^{19}$. Cutaneous lichen planus has been reported to occur in patients with cancer, gastrointestinal disease, stress and various viral infections ${ }^{28}$. In oral lichen planus, stress has been found to be the most frequent precipitating factor leading to flare-up in some patients ${ }^{39}$. This was supported in a case-control study with 46 patients, where major life events or stress had been a factor in both onset and the duration of lichen planus ${ }^{65}$.

In oral lichen planus, there are reports on malignant transformation into squamous cell carcinoma (SCC). A review of several observational studies with a total of 7,806 patients with oral lichen planus showed a SCC incidence of $1 \%{ }^{66}$. In genital lichen planus, the incidence of SCC in smaller studies has been reported to be between 1 and $3 \%^{57,58,62}$. SCC may appear after several years of GELP, but the long-term risk of vulval carcinoma remains unclear ${ }^{57}$. The vestibular area between 
the clitoris and the urethra is known as the typical site for this malignant transformation. Lichen planus-associated SCCs are regarded as aggressive malignancies with a high rate of regional lymph nodes metastases. In one case series, vulval SCC had an aggressive course with inguinal metastases and was cause of death in 16 of 38 women with genital lichen planus ${ }^{66}$.

\section{TREATMENT}

Daily hygiene and intimate care are essential, and efforts to reduce irritation must be made. The patients are advised to use a soap substitute or diluted emulsifying ointment. It is important to reduce heat, sweating, friction and use of panty liners. Sporting activities like horse riding, bicycling and indoor swimming may increase the symptoms and should be avoided. Incontinence may induce increased soreness, requiring medical intervention.

Most clinicians will prescribe topical application of high-potent corticosteroid ointments on vulval lesions and lower-potent corticosteroid foam on vaginal lesions, which needs to be used intermittently for many years, most often life-long ${ }^{67,68}$. Although this treatment is regarded as being the first choice of treatment, the effect is not documented scientifically. In the vulva, clobetasol propionate $0.05 \%$ is mostly used once daily for 1-2 months, and then tapered slowly until a maintenance application of 1-2 times per week. Flare-ups are frequent and require daily application for weeks or months $s^{9,58,68}$. In the vagina, hydrocortisone vaginal foam $10 \%$ or sometimes clobetasol propionate $0.05 \%$ may be used, initially once daily for some months, and then the frequency is tapered down as in the vulva ${ }^{9}$. Intralesional injections of triamchinolol acetonide may be considered ${ }^{69,70}$.

Other topical treatment options are calcineurin inhibitors, such as tacrolimus or pimecrolimus $^{71,72}$. Tacrolimus reduces T-lymphocyte activity by inhibiting proinflammatory interleukins and does not affect keratinocytes and collagen, thereby not causing cutaneous atrophy, but may induce burning pain and discomfort during and after application.

Vaginal dilatators, used daily or weekly may be necessary to prevent stenoses and obliterations of the vagina, in some cases for many years, even life-long. The size of the dilatators has to be adjusted to the size of the vagina. If regularly manual dilatation is insufficient, surgical $\mathrm{CO}_{2}$ laser vaporization is an option in order to open up vulval and vaginal synechies. 
Systemic treatment is relatively seldom used. First choice systemic treatment is prednisolone $40-60 \mathrm{mg}$ per day for 2-6 weeks $\mathrm{s}^{67,73}$. Short-time treatment is reported to be safe, effective and well tolerated, but maintenance treatment is controversial and may lead to a wide variety of adverse effects ${ }^{74}$. The use of other systemic drugs, including retinoids, methotrexate, cyclophosphamide, azathioprine, hydroxychloroquin, mycophenolate and cyclosporine, in GELP have been reported although the effect is not scientifically documented $d^{57,58,73,75,76}$.

Patients may experience symptomatic improvement, but erosions tend to persist, and long-time treatment may end up with adverse effects, tachyphylaxia and reduced patient compliance. Typical local adverse effects from topical corticosteroids include skin atrophy, striae, increased skin fragility, telangiectasia, herpes simplex and contact allergy. Candida infections are frequent, with symptoms difficult to separate from GELP activity, as itching and redness are frequent symptoms in both diseases. With any of these treatments, GELP tends to recur after treatment is discontinued ${ }^{31}$ and requires intermittent or continuous long-term therapy over an indefinite time $e^{9,77,78}$.

There are few published studies on GELP treatment, most of them being case reports and small case series ${ }^{79}$. On a literature search in MEDLINE and in the Cochrane databases, we were unable to find any randomized controlled trials (RCT) or observational cohort studies comparing different treatment modalities for GELP. The Cochrane Collaboration found only weak evidence for the effectiveness of any of the treatment options in oral lichen planus, and did not find any RCT on GELP ${ }^{80}$.

In summary, there are very few clinical studies on GELP and no evidencebased treatment available. New and more effective treatment modalities are required, preferably investigated in RCT studies.

\subsection{The Vulva Clinic in Oslo}

Cutaneous and mucosal changes seen in vulval dermatoses may easily be missed or misdiagnosed by physicians without experience in dermatology and gynaecology. Dermatologists may have limited or no experience in gynaecology and many gynaecologists have little or no experience in dermatology, causing confusion and frustration among patients. Vulval diseases are associated with social taboos, and patients may seek medical attention from different health care workers, mostly 
general practitioners, dermatologists, venereologists and gynaecologists. These factors cause problems in both treatment and research ${ }^{8}$. In Norway, knowledge of genital dermatoses is limited as this subject is not covered specifically in the specialist educational program.

Acknowledging the interdisciplinary aspects of vulval disorders, specialized vulva clinics have been established in several countries, mostly with dermatologists and gynaecologists; in the United Kingdom also with specialists in genito-urinary medicine. In Norway, the first vulva clinic was opened in 2000 with only one specialist ${ }^{81}$. In 2003, the first interdisciplinary vulva clinic was established at the Department of Obstetrics and Gynaecology, Rikshospitalet ${ }^{82}$.

This clinic is now a national referral centre for women with vulval chronic pain, sexual dysfunctions, infections, and dermatoses of the genital area. The majority of the patients have a chronic pain disorder, mainly localized provoked vulvodynia, while 20 and $30 \%$ of the patients referred to the Vulva Clinic have a genital dermatosis $^{82}$. In 2015, more than 700 consultations were carried out, about half of the patients living in the south-east region of Norway. Two dedicated gynaecologists and one dermatologist are employed with two half-day patient sessions per week.

Other health care professionals, such as pathologists, physiotherapists, psychologists, sexologists, venereologists and specially trained nurses, are also involved. Since 2003, the number of referrals has increased considerably, resulting in long waiting lists.

\subsection{PHOTODYNAMIC THERAPY}

Photodynamic therapy (PDT) is not a new concept ${ }^{83}$. Although there are evidence of photosensitization reactions in the writings of the Egyptians, Indians and Chinese dating to at least 30 centuries ago, the modern era of photosensitizing as a science started in 1900, when a German medical student was studying the effect of histological dyes on unicellular organisms in the light of a microscope. He discovered that the cells gradually lost motion and were unable to divide, because of the illumination from the microscope. His mentor termed this a "photodynamic effect", and suggested this to be used in clinical medicine ${ }^{84}$. 
PDT requires three essential components: a photosensitizer, light and oxygen. The administration of a photosensitizing drug followed by light exposure will lead to a phototoxic reaction causing tissue destruction (Fig 2).

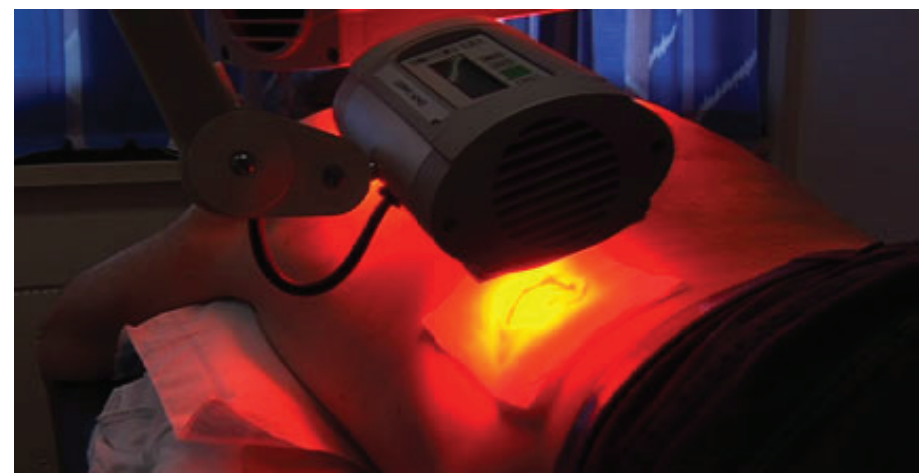

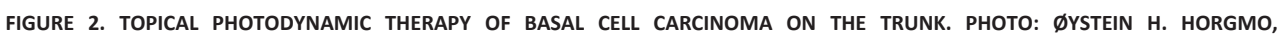
WWW.ONCOLEX.NO

Systemic or topical application of a photosensitizing compound leads to a more or less specific accumulation of this photosensitizer within cells and tissue. Thereafter light is used to activate this photosensitizer, generating reactive oxygen species, which in turn leads to tissue and cell damage ${ }^{85}$.

The wavelength of the light source is selected according to the absorption characteristics of each photosensitizer. The interaction between light and the photosensitizer results in generation of unstable, high-energy singlet oxygen and oxygen radicals, and these reactive oxygens have a local cytotoxic effect ${ }^{85}$.

\section{Photosensitizers}

The chemical compounds used as photosensitizers can be classified into three families: dyes (such as phtalocyanine and naphtalocyanine), chlorophyll-based (such as chlorins, purpurins and bacteiochlorins) and porphyrin-based (such as photophrin and aminolevulinate acid (ALA)). The first clinical reports of PDT used dyes as photosensitizers, but porphyrin extracts rapidly became the most widely studied photosensitizer. The first generation of photosensitizers was administered systemically, but these had significant adverse effects limiting the clinical use, most importantly long-lasting skin sensation to visible light ${ }^{86,87}$. 
In the late1980s and early 1990s, several photosensitizers for topical administration were developed. The topical application method is attractive for treatment of superficial epithelial disorders avoiding systemic adverse effects, and has been used increasingly in the last decades, especially in dermatology. PDT has become a well-established treatment for several premalignant and malignant skin diseases, such as actinic keratoses, superficial basal cell carcinoma (BCC) and carcinoma in situ (Bowen's disease) Used in well-selected cases, PDT is highly effective, with few recurrences and with excellent cosmetic results ${ }^{87-89}$.

5-aminolevulinic acid (ALA) and its methyl ester, methyl 5-aminolevulinic acid (MAL) are the two main precursors for topical porphyrine PDT in use today. Both are precursors of an endogenous photosensitizer, protoporphyrin IX (PpIX), which is a part of the heme cycle, expressed at a low level in all nucleated cells (Fig 3).

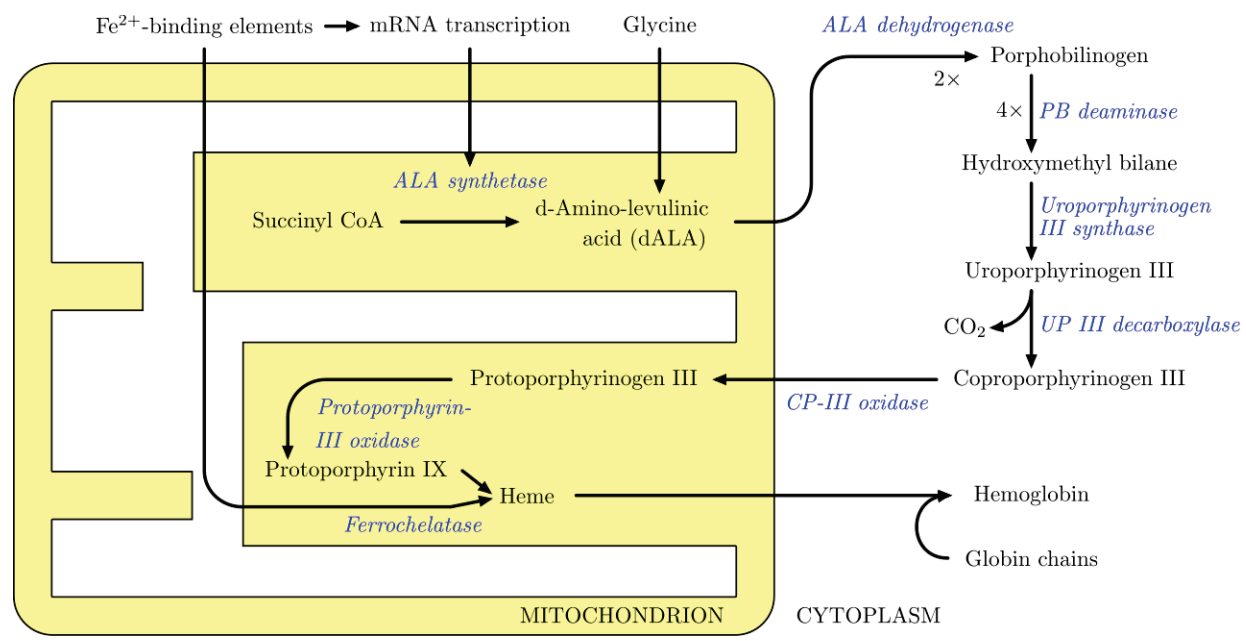

FIGURE 3. PROTOPORPHYRINE IX AND THE HEME BIOSYNTHETIC PATHWAY. WIKIPEDIA, HEME SYNTHESIS. (HTTP://UPLOAD.WIKIMEDIA.ORG/WIKIPEDIA/COMMONS/A/A9/HEME SYNTHESIS.PNG

After application, the precursor is absorbed into cells and converted via the heme cycle to PpIX. Different rate limiting steps, such as ferrochelatase activity and alterations in heme biosynthetic enzymes, mitochondrial functions and porphyrin transporters, result in accumulation of PpIX in abnormal cells, with relatively less accumulation in surrounding normal cells ${ }^{85,89,90}$. Light absorption by PpIX generates reactive oxygen species, which are cytotoxic to cells if the light dose and oxygen 
supply are sufficient. Also, PpIX itself is degraded by the reactive oxygen species, such photobleaching of the photosensitizer may limit the damage that PDT can induce in tissue. As PpIX itself is fluorescent, this property can be used for diagnosis, monitoring the build-up and photobleaching in vivo, or to study the biodistribution of the photosensitizer in frozen tissue sections.

Due to suboptimal penetration of the hydrophilic ALA through tissues and into thick lesions, more lipophilic esters of ALA were introduced in mid 1990s to improve the bioavailability in tissue ${ }^{91-93}$. MAL is the methyl ester of ALA. Topical MAL is licensed in Europe for the treatment of actinic keratosis, BCC and carcinoma in situ (Bowen's disease).

Hexyl 5-aminolevulinic acid (HAL), by the addition of a long-chain hydrocarbon, is a more lipophilic ester derivate of ALA and is equally metabolized to ALA by non-specific esterases within the target cell. When compared to ALA, HAL leads up to 25-fold increase in PpIX fluorescence level ${ }^{94}$.

The advantage of HAL versus MAL is low drug concentration, short administration time and deep tissue penetration ${ }^{95-97}$. In cervical carcinoma, HAL is able to penetrate across biological barriers in a significant faster manner, has a higher porphyrine formation and induce highest level of phototoxity compared to ALA and other ALA esters ${ }^{98,99}$. HAL-based PDT also seems to be better tolerated than MAL-based PDT, with less pain, according to own experience. In one study using healthy volunteers, side effects like erythema and burning resolved earlier after HALbased PDT ${ }^{100}$.

$\mathrm{HAL}$ is approved for the detection of cancer in the urinary bladder by means of fluorescence cystoscopy ${ }^{93,99,101,102}$.

\section{LIGHT SOURCES}

The aim of the light source in PDT is to activate the photosensitizer localized in the tissue. As mentioned earlier, the wavelength of the light source is selected according to the absorption characteristics of each photosensitizer. Several types of light sources have been used in topical PDT. Technically advanced lasers were in use in the 1990s, while broad band lamps, light emitted diodes (LED) as well as daylight were introduced later ${ }^{103}$. Lasers give coherent and monochromatic light, while the other light sources give non-coherent and generate wavelength bands wider than those from the lasers ${ }^{104}$. 
To activate the photosensitizer, the spectral output of the light source should correspond to the excitation peaks of the photosensitizer. The porphyrine photosensitizer PpIX has a major peak of excitation at $410 \mathrm{~nm}$ in the blue-violet part of the light spectrum (Fig. $4^{105}$ ).

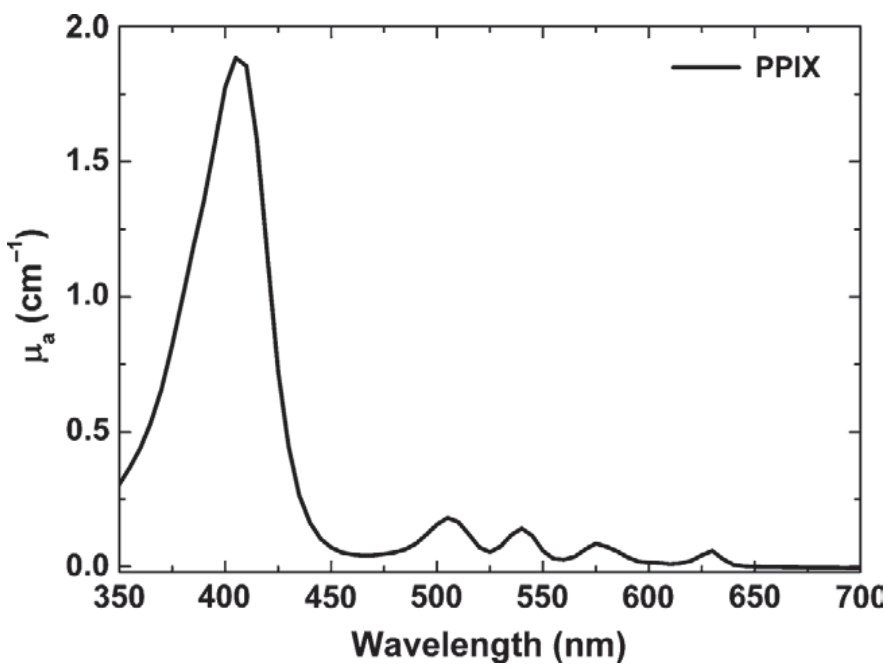

FIGURE 4. PROTOPORPHYRINE IX (PPIX) FLUORESCENCE EMISSION SPECTUM. VALENTINE, J BIOMED OPT 2011.

At this wavelength the light has a very poor tissue penetration of less than $0,5 \mathrm{~mm}$. PpIX has in addition a smaller peak in the red light region at 630-636 nm, giving a deeper tissue penetration ${ }^{106}$. This makes red light a more suitable light source. Both laser and non-coherent light can emit red light. In a clinical study comparing effectiveness of laser vs. broad band lamp in the treatment of BCC, there was no difference between the two groups. The less expensive broad band lamp was preferred for security and economic reasons ${ }^{107}$. Portable LED lamps, easy to use and less expensive than lasers, are now being widely used in $\mathrm{PDT}^{104}$. 


\section{Clinical applications}

As mentioned previously, topical PDT with ALA or MAL as photosenisitizers has become established treatment options for actinic keratosis, superficial BCC and carcinoma in situ with acceptable cure rates and excellent cosmetic results ${ }^{87,88,108,109}$.

The range of new indications for PDT, however, is expanding. PDT may also have therapeutic benefits in cutaneous T-cell lymphoma ${ }^{110}$ and has been used in Kaposi's sarcoma, extra-mammary Paget's disease and cutaneous B-cell lymphoma ${ }^{111-113}$. Topical or systemic PDT has been used in precancerous and cancerous lesions in the oesophagus ${ }^{114}$, upper aero-digestive tract, lungs, oral cavity $^{115}$ and cervix ${ }^{98}$. Moreover, PDT can be used supplemental to surgery by irradiating the tumour bed and thus increase the probability of long-term local disease control $^{116}$.

PDT has also been introduced in vulval intraepithelial neoplasia (VIN) and vaginal intraepithelial neoplasia treating multi-focal involvement and avoiding tissue loss. Treatment results are encouraging with an overall cure rate of $40-70 \%$, similar to results after surgical excision or laser evaporization ${ }^{117,118}$. In addition, HAL-based PDT has shown promising results in cervical intraepithelial neoplasia (CIN) grade 2 , including a clearance of oncogenic types of human papilloma virus (HPV) ${ }^{119}$ and is currently entering late-phase clinical trials for high-grade $\mathrm{CIN}^{120}$

The intracellular accumulation of PpIX is not tumour-specific, but may also be localized in the inflammatory infiltrate of several inflammatory skin disorders, both non-infectious and infectious diseases. The response of PDT seems to be good in both acne, common warts and leishmaniasis, but not in psoriasis ${ }^{121-123}$.

In acne, the effect of PDT is thought to be induce by a selective destruction of the sebaceous unit after up-take of the photosensitizer, either ALA or MAL ${ }^{124},{ }^{125}$. In general, inflammatory acne lesions seem to respond well to PDT, whereas comedonal and non-inflammatory acne lesions tend to show no significant change ${ }^{103}$. In common warts, clearance rates after PDT are reported to be as high as $88 \%$ without significant adverse effects ${ }^{126}$. A positive effect of PDT on cutaneous leishmaniasis has been shown in case reports and small case series PDT ${ }^{121}$.

PDT has also been used in mucosal inflammatory disorders such as oral lichen planus ${ }^{127-129}$ and genital lichen sclerosus ${ }^{130-132}$, using topical methylene blue, ALA or MAL as photosensitizers. In a Norwegian study, one session with MAL-PDT 
in oral lichen planus resulted in long-lasting, clinical significant improvement for up to 4 years $^{133}$. This is supported in a review article on PDT in oral lichen planus ${ }^{134}$.

In a small, non-controlled study in 28 women with lichen sclerosus, PDT resulted in partial or full remission of symptoms in 25 women with loss of typical histopathological findings in 10 women ${ }^{135}$. Another study using repeated cycles of PDT in lichen sclerosus, reported significant symptom relief after 6 weeks, but no effect on histopathological findings ${ }^{131}$.

\section{COMPLICATIONS AND ADVERSE EFFECTS}

Adverse effects of PDT in premalignant and malignant skin disease are generally mild and transient. However, a majority of patients will experience pain or discomfort during and immediately after the procedure. In addition to local burning pain, itch and a stinging sensation, erythema and oedema can occur at the treated area immediately after illumination ${ }^{87,136}$.

The pain mechanism is unclear, and the pain is generally unpredictable. The pain is at its highest level at the beginning of the illumination, possibly due to the highest amount of active PpIX production in the beginning of the irradiation process, giving a peak phototoxic effect. It may be a consequence of this photochemical reaction and related to the presence of reactive singlet oxygen ${ }^{87,137}$.

Adverse effects from PDT are less studied in genital and mucosal disease. In a study using HAL-based PDT on CIN, no permanent damage in the cervical tissue was found. Cervix was illuminated with $50 \mathrm{~J} / \mathrm{cm}^{2}$ red coherent light $(633 \mathrm{~nm}$ ) using a special light catheter. Adverse reactions were mild to moderate, local and self-limiting and included discharge, discomfort, spotting and vaginal cramps during illumination. The treatment was relatively easy to perform and well accepted by the patients ${ }^{119,138}$. In studies on VIN, the tolerance to PDT seems to vary. In an ALA-based PDT study in VIN, the discomfort rapidly increased during illumination, with a peak after 4 minutes. Two weeks after ALA-PDT, all patients were free of discomfort ${ }^{139}$. A burning and stinging pain was described, most intense at the clitoris and peri-urethral area and in widespread lesions ${ }^{117,139}$. In studies using PDT in vulval lichen sclerosus, the adverse effects were tolerable, but sometimes long-lasting ${ }^{130,131}$. 


\section{AIMS OF STUDIES}

GELP is a chronic inflammatory autoimmune disease, in women characterized by painful erosions in vulva and vagina. There are some case series published, most of which have focused on the vulval involvement of the disease.

We set out to describe the clinical and histopathological findings in women with GELP diagnosed at the Vulva Clinic in Oslo, Norway in the period 200309, with a special emphasis on treatment, vaginal involvement and its influence on sexual function (Paper I).

Treatment of GELP is unsatisfactory, and there are no authoritative treatment guidelines. To our knowledge, there are no published RCTs regarding GELP. PDT has shown promising results in several mucosal diseases, including oral lichen planus and lichen sclerosus. HAL, a lipophilic ester of ALA, has been studied in other genital mucosal conditions, such as CIN and VIN, and is approved for the detection of bladder cancer, and seems to be well tolerated.

We set out to study the biodistribution of PpIX after topical application of HAL gel on normal and affected mucosal surfaces in women with GELP in order to determine an adequate dosage and application time of HAL to be used in a RCT on vulvovaginal PDT in GELP (Paper II)

We set out to conduct a RCT in women with GELP, comparing one session with vulvovaginal HAL-based PDT with daily application of topical corticosteroids for six weeks, assessing the feasibility, effect and safety of vulvovaginal PDT in GELP (Paper III). 


\section{METHODOLOGICAL CONSIDERATIONS}

\subsection{CASE SERIES}

A case series is a descriptive study that follows a group of patients who have a similar diagnosis or who are undergoing the same procedure over a certain period of time $^{140}$. Reports of case series usually contain detailed information about individual patients and information on diagnosis, treatment, response to treatment and followup after treatment. Although inferior to a larger-scale research project, a case series has a useful role in medical research in being able to detect important new findings and provide new ideas and knowledge ${ }^{141}$. Case series can also detail different aspects of patients' medical situation.

The clinical spectrum of relatively rare diseases, such as GELP, can be detected and highlighted in case series. Some case series on GELP have been published, mostly focusing on treatment outcomes ${ }^{36,58,59,73}$, including one from Scandinavia ${ }^{142}$. The frequency and degree of vaginal involvement of GELP in these publications varies or was not reported.

There are, however, several important disadvantages of a case series. There are no comparison groups, and conclusions on the effect of treatment cannot be drawn $^{143}$. A case series is also subject to selection bias because the clinician or researcher self-selects the cases. In our case series, all women diagnosed with GELP at the Vulva Clinic in Oslo were included. At this clinic, we had records on 58 patients with GELP, all referred to and diagnosed, treated and followed-up regularly since 2003. They were identified in the patient file registry by searching for the diagnosis L43.9 Genital erosive lichen planus in the ICD-10 (International Classification of Diseases). The diagnosis had been made clinically by at least one of three specialists working at the clinic.

The case series reported in Paper I is retrospective. The availability and accuracy of the clinical data varied. Major limitations of the study include the use of referral documents for the reporting of past treatment and the use of three doctors conducting the clinical examinations. The diagnostic criteria of GELP were based on the clinical appearance of typical mucosal lesions, in some cases supported by histological diagnosis. We used the best clinical and histopathological criteria available at that time, as there was no international consensus on such criteria. 
A majority of the patients gave information about their sexual activity, but not all patients reporting sexual abstinence were asked why they were not sexually active. With a median age at the time of diagnosis being 56 years, some women may have had other reasons for sexual abstinence, including partner-related issues.

\subsection{METHODS FOR DETECTING PROTOPORPHYRIN IX}

In order to detect the PpIX fluorescence, two different methods were used: superficial fluorescence measurement (Paper II and Paper III) and microscopic fluorescence photometry (Paper II).

Superficial fluorescence measurement was introduced in 1986 and made it possible to monitor the accumulation and photo-bleaching of a photosensitizer at the surface of the target lesion versus normal skin ${ }^{144}$. This technique can be used to monitor the PpIX- fluorescence in GELP lesions after HAL application. The data will be able to show how the intensity and selectivity of PpIX fluorescence is dependent of HAL application time.

In the study reported in Paper II, superficial HAL-induced PpIX fluorescence was measured at baseline, after 30 minutes, 1 hour and 3 hours in both diseased and normal tissue. After 3 hours, superficial fluorescence was also measured in the distant head and neck area, in order to register a possible systemic uptake of HAL. Accumulation and photo-bleaching of HAL-induced PpIX was monitored on the genital mucosa with this non-invasive in situ measurement. A bifurcated fibre optic probe (FCB-UV600-2, Avantes, Eerbeek, Netherlands) was oriented perpendicular to the tissue surface and connected to a spectrometer (S2000, OceanOptics, Dunedin FL, USA) and a $405 \mathrm{~nm}$ diode laser (PPMT-LD1381, Power Technology, Little Rock AR, USA). The system delivered a $70 \mathrm{~ms} 0.1 \mathrm{~mJ}$ pulse of excitation light to a $7 \mathrm{~mm}^{2}$ sample area. The emitted fluorescent light was collected with a numerical aperture of 0.21. Linear combinations of a PpIX standard spectrum and a fourth degree background function were fitted by least square estimation to the recorded spectra in order to quantify the degree of PpIX fluorescence. The PpIX standard spectrum was measured from a $1 \mathrm{~mm}$ quartz cuvette (Perkin Elmer, Wellesley, MA) filled with a 5 $\mu \mathrm{g} / \mathrm{ml}^{-1}$ PpIX (Sigma-Aldrich, St Louis MO, USA) solution. PBS with $10 \%$ foetal calf serum was used as a solvent to imitate the chemical environment found in tissues, but the PpIX was first dissolved in $1 \mathrm{M} \mathrm{HClO} 4$ in $50 \% \mathrm{MeOH}$ to a $0.5 \mathrm{mg} / \mathrm{ml}^{-1}$ stock 
solution. Each value at any time point represents in fact the mean/median value of a series of at least five repeated measurements.

This superficial method is not as differentiated and reliable as the microscopic fluorescence photometry method ${ }^{145}$. Although there are large inter-individual differences, the superficial measurements will confirm local PpIX induction and give information on an eventual systemic uptake of HAL. In Paper III, the same method was used immediately before and after treatment in order to monitor the accumulation and photo-bleaching of HAL, and to measure possible systemic uptake of HAL.

By microscopic fluorescence photometry, the biodistribution of a photosensitizer in the tissue after topical application may be investigated ${ }^{146}$. Microscopic fluorescence photometry basically consists of a fluorescent microscope, a light-sensitive camera and image analysis software. With this technique it is possible to study distribution pattern of a fluorescent photosensitizer in tissue. In Paper II three biopsies from each patient were sampled, immersed in liquid nitrogen and stored at $-80^{\circ} \mathrm{C}$. The tissue blocks were mounted in a medium (Tissue Tek II embedding compound, BDH, Poole, UK) and cut with a cryostat microtome to slices with $8 \mu \mathrm{m}$ thickness and mounted on clean glass slides. Three different microscopic images were used from each biopsy: a white light image, a haematoxylin \& eosinstained image of an adjacent section and a fluorescent image of HAL-induced PpIX made by means of microscopic fluorescence photometry.

HAL-induced PpIX fluorescence measurements were done by the microscopic fluorescence photometry using a microscope (Nikon Eclipse E800) with a 100W mercury lamp, a highly light-sensitive thermo-electrically cooled charge-coupled device camera (ORCA ${ }_{\| I}-E R$, Hamamatsu, Japan) and Aqua Cosmos image analysis software (Hamamatsu Photonics). A 390-440 nm excitation filter, $460 \mathrm{~nm}$ beam splitter and 610-650 nm emission filter were used to image PpIX fluorescence. All images were corrected for non-uniform illumination using images of a fluorescence standard. An exposure integration time of 15 seconds was used. To quantify the induced bleachable porphyrin fluorescence, we subtracted the background autofluorescence. Sample images were taken before and after bleaching most of the fluorescence by exposing the sample to excitation light for ten minutes. The second image was subtracted from the first to provide an image of pure bleachable porphyrin 
fluorescence and corrected for most auto fluorescence and other background sources.

Data acquisition was made with the Aqua Cosmos software; and the fluorescence intensity of each pixel within the selected area was digitalized and plotted as a function of depth of the lesion. The area under the curve (AUC) of each plot was measured and presented as AUC per $\mathrm{mm}$ in depth because of a diverse depth of epithelial and submucosal tissue in different lesion samples. Measurements were carried out in a blinded manner with respect to the concentration and application time of HAL.

\subsection{BIOPSIES}

The genital mucosa is a sensitive area, and in the interest of the patients, the number of biopsies was kept to a minimum.

In most patients in the biodistributional HAL-study (Paper II), three punch biopsies or forceps biopsies were taken from the vulva or the vagina; two from affected mucosa and one from clinically normal mucosa. The mucosal location of the biopsies varied considerably due to different degree and location of the mucosal lesion, often having a scattered appearance. In some cases, it was difficult to find suitable areas for taking a biopsy.

As the vulvovaginal epithelium in GELP patients may be thin and fragile, it may be difficult to take an adequate biopsy. The mucosal $4 \mathrm{~mm}$ biopsies tended to reshape to a circular ball immediately after removal. The biopsies were oriented on a piece of carrot, which was an advised technique ${ }^{147}$, and immediately put into liquid nitrogen. Thus, some of the biopsies were difficult to orientate and impossible to prepare for further technical analysis. Because of this, we were able to include only 26 out of 36 biopsies for histopathological investigation.

\subsection{RANDOMIZED CONTROLLED TRIALS}

RCTs are considered to be the gold standard for a clinical trial. RCTs provide the most reliable evidence on the effectiveness of therapeutic interventions, because RCT minimize the risk of confounding factors influencing the results. Because of this, 
the findings generated by RCTs are likely to be closer to the true effect than the findings generated by other research methods ${ }^{148}$.

To our knowledge, no other RCT on GELP exclusively has been published. One reason for this may be the limited number of patients with GELP available for clinical research. Another reason is linked to the nature of the disease, with regular exacerbations and acute flare-ups, making long-lasting follow-ups necessary in clinical trials. We have identified only one other RCT conducted on different subtypes of vulval lichen planus, comparing aloe vera ointment and placebo ${ }^{149}$.

In many countries, the general population consists of people of different races and ethnic groups. One of the advantages of a study conducted in Norway, is a relatively homogenous population, both in social-economic and racial terms. Our studies were conducted at the Oslo University Hospital (OUS), with patients recruited from all parts of the country. Because of the rather extensive degree of therapeutic intervention of vulvovaginal PDT, a selection bias is presumed regarding the willingness to participate, excluding patients with less pain and involvement. Two patients declined to participate because of the uncertainty regarding the outcome and possible adverse effects resulting from the lack of earlier clinical experience in PDT on GELP.

No specific outcome measure tools have been designed specifically for vulval diseases. In other RCTs on vulval skin disorders, patient-reported outcome measures are more commonly used than clinician-reported outcome measures ${ }^{150}$. The design of our RCT with both subjective and objective outcome measures strengthens the validity of the outcome measures.

\subsection{CLINICAL SCORES}

There is no consensus on outcome measures in vulval disease. There are no published RCTs exclusively on GELP ${ }^{80,150}$. The absence of validated instruments for clinical grading of GELP may be due to the fluctuating clinical nature of the disease, and the difficulties in measuring the affected areas in the vulva and the vagina.

In Paper III, we report the results as physician-reported clinical severity score (GELP score) and patient-reported symptom score, i.e. pain recorded on a visual analogue scale (VAS). The GELP score was created as a clinical composite grading tool for use in this study, for details see Paper III. A preliminary version of the GELP 
score was used and evaluated by two doctors at the Vulval Clinic for several months before the start of the RCT. The doctors examined the same patient separately during the same consultation. The results were compared and discussed afterwards, and the GELP score modified accordingly. The scoring system was not extensively validated, but includes a severity assessment in four out of five clinical diagnostic criteria for GELP in an international web-based Delphi consensus report ${ }^{62}$.

Some of the variables were difficult to rate, especially the area of involvement in the vagina, due to possible stenosis or extensive pain during examination. Not surprisingly, we observed different results on the vaginal GELP score while having the patient sedated during the illumination, as the natural folds and roughness were smoothed, making the visual area grading easier. This was an interesting observation, not possible to implement in the regular GELP scoring procedure.

Several different techniques have been used to quantify and assess pain and cutaneous mechanical hyperalgesia ${ }^{151,152}$. In a recent study on pain assessment in vulvodynia, filament algesiometers (von Frey) were found to be less suitable than VAS scores for cotton swab-induced pain and clinical parameters like subjective pain (VAS) and objective focal redness ${ }^{153}$. We used two different VAS scores for pain in Paper III, one in which the doctor assessed the pain applying a tender pressure with a cotton swab on the most inflammatory area of the vulva and the vagina separately. The other was a weekly recording of pain VAS score done by the patient.

The weekly use of topical corticosteroids was reported by the patients in their log. This was carried out very carefully by almost all patients.

\subsection{Vulvovaginal PDT PROCEDURES}

The practical procedures and technical equipment used for HAL-PDT reported in Paper III were as followed:

A pre-treatment screening was done with measurements of vital functions. In each patient, $2 \mathrm{ml}$ of HAL $6.25 \mathrm{mg} / \mathrm{ml}$ gel was applied to the affected areas in the vulva or the vagina. The vulva was then covered with adhesive plaster and the patients were kept in a horizontal position for 3 hours without urinating. A surface fluorescence measurement was done on the treatment area before and after illumination to assess the degree of photobleaching. This measurement showed that more than $90 \%$ of the PpIX was bleached. 
After inducing the appropriate sedation, the illumination was started. To be able to illuminate inside the whole circumference of the vaginal mucosa, we chose to use a $633 \mathrm{~nm}$ diode laser providing a total light dose of $75 \mathrm{~J} / \mathrm{cm} 2$, with special equipment for luminal PDT. A cylindrical light diffuser between 3-7 cm lengths was positioned centrally in a cylindrical glass probe of the same length, to fit the vaginal size or the involved area (Fig 5). The light fluency rate varied between 40-100 mW/cm2, depending on the length of the cylindrical light diffuser and the diameter of the vaginal glass probe. Calculations were made to estimate the illumination time. The illumination time varied accordingly between 1000 and 2670 seconds.

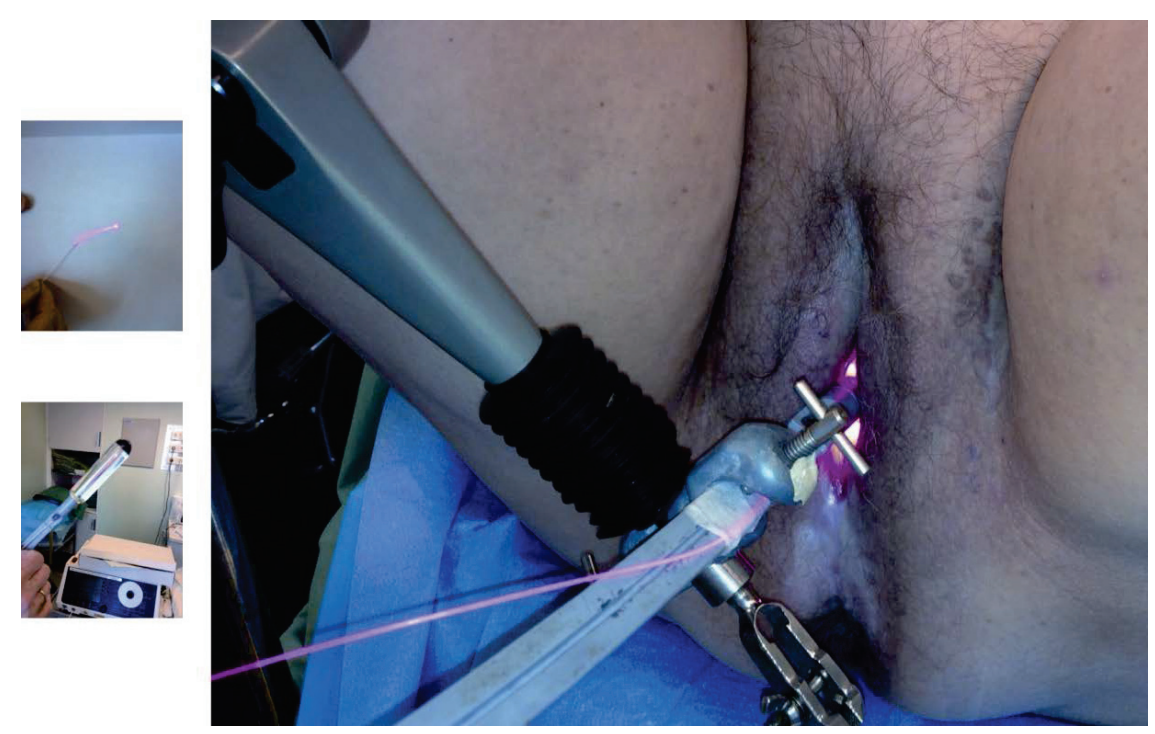

FIGURE 5. THE SIZE OF THE CYLINDRICAL LIGHT DIFFUSER GLASS PROBE (A) AND THE CYINDRICAL GLASS PROBE (B) WAS CUSTOMIZED TO THE LENGTH OF THE VAGINA. THE CYLINDRICAL LIGHT DIFFUSER WAS THEN PUSHED CAREFULLY INTO THE GLASS PROBE (B) AND FINALLY APPLIED IN THE VAGINA FOR THE ILLUMINATION, ATTACHED IN A FIXATION DEVICE (C).

In the vulva, the illumination was performed with the same $633 \mathrm{~nm}$ laser, using a frontal light distributor. During this procedure, the labia majora were held to each side manually to make sure the whole vulval surface was illuminated. The meatus of urethra was mostly covered by an aluminium tape to avoid tissue inflammation and dysuria. Lidocaine 5\% gel was applied immediately after illumination, and all the patients left the hospital after 1-3 hours. 
Some of the involved areas in the vagina may not have been properly illuminated, due to scattered involved areas or inoperable obliterations. In these cases, the size of the glass probe or the length of the light diffuser was partly insufficient.

\subsection{AdVERSE EFFECTS}

This being the first study on HAL-based PDT in a non-malignant inflammatory genital disease, we had limited information from the literature on possible adverse effects. We were particularly concerned about PDT-induced pain during illumination and possible development of new or more synechies after PDT.

According to this, the first six patients receiving vulvovaginal PDT were set up as a pilot study to investigate the feasibility of the procedure and its possible initial adverse events. These patients were subject to an extra follow-up after one week and subsequently included in the main trial. Side effects registered at week 1 and week 6 were considered as minor events. Consequently, the continuation of the study was approved by the Norwegian Medicines Agency.

The soreness and/or pain immediate after PDT varied inter-individually, and seemed to be related to the size of the involved area. This is also reported in a study of 658 photodynamic treatments in 377 patients in non-malignant skin disease ${ }^{154}$. Our impression was that vulval PDT induced more soreness and pain than vaginal PDT. Similar vulval side effects have been reported after PDT in lichen sclerosus and VIN ${ }^{130,131,155}$.

\subsection{Statistical CONSiderations}

The RCT was originally designed as a non-inferiority trial. A non-inferiority trial is intended to show that the effect of a new treatment is not worse than that of an active control treatment by more than a specified margin ${ }^{156}$. It should be recognized that the results of such trials are not as credible as those from a superiority trial ${ }^{157}$. Noninferiority trials have a number of inherent weaknesses that superiority trials do not have, including difficulties in specifying the non-inferiority margin ${ }^{158}$, as was the case in our study reported in Paper III. 
Non-inferiority trials may be useful when a placebo group cannot be ethically included, like in our study (see ethical considerations). Topical corticosteroids are usually the first choice of treatment in GELP, although their effect have not been documented in placebo-controlled RCTs ${ }^{57,159}$. Other studies, including our own retrospective case series, have indicated that $60-70 \%$ of the patients will have clinically significant effect of topical high-potent corticosteroids $36,58,160,161$. In a study using HAL-PDT on oral lichen planus, nine out of 11 patients reported clinical effect four years after one PDT session ${ }^{133}$. Combining this clinical and statistical experience, we assumed that vulvovaginal PDT in GELP would be equally effective as topical high-potent corticosteroids, but having other benefits such as fewer and less adverse events, particularly regarding cutaneous and mucosal atrophia, and better patient compliance. The suggested non-inferiority margin was set to $20 \%$, although highly uncertain. It was not realistic to expand sample size above 20 in each patient group due to the small patient population from which to recruit study participants.

We were not able to show no-inferiority between one session with vulvovaginal PDT and daily application of topical corticosteroids for six weeks. This may be explained by unrealistic assumptions of efficacy and efficacy difference, reflected by the lower response rates from topical corticosteroids in our study than reported in previous studies. The results were instead presented as a conventional superiority RCT, using two-sided statistical test ${ }^{162,163}$.

A RCT analysed by the intention-to-treat approach provides unbiased comparisons among the treatment groups and avoids the effects of dropout, which may break the random assignment to the treatment groups in a study ${ }^{164}$. In our study, the results would have been even more reliable with an intention to treat-analysis, as three patients in the control group dropped out of the study the first 1-3 weeks. We have no reason to believe that their baseline characteristics or possible response of treatment could explain why they dropped out. We therefore assumed that they could be treated as missing completely at random, and that this would not bias our results.

In our RCT study, the weekly use of topical high-potent corticosteroids was noted in the patients' log books. The reduced use of topical corticosteroids in weeks 7-24 after PDT may be of great importance in assessing the effect of vulvovaginal PDT in GELP. 


\subsection{ETHICAL CONSIDERATIONS}

The studies were conducted in accordance with the Declaration of Helsinki and in accordance with national and local regulations. The Regional Committee for Medical Research Ethics in South-east Norway and the Scientific Advisory Board and the Data Protection Officer at Oslo University Hospital approved the trial protocols before recruiting study participants.

In the studies reported in Paper II and Paper III, written informed consents were obtained from all study participants. Both studies were approved by the Norwegian Medicines Agency and registered at EUDRA CT-Nr 2008-000950-11 and 2010-021949-40 and in Clinical Trials.gov (CT 01282515) prior to study start.

The optimal design of a HAL-PDT trial would have been to compare HAL-PDT with placebo. This was considered ethically not acceptable, as we could not expect the patients in the control group to be without corticosteroids for up to 6 months. Many of the patients would suffer from pain, itch and bleeding and possibly developing new or more synechies in the absence of any active treatment for an extended period such as 6-24 weeks.

The design of the RCT would also have been stronger if the patients in the PDT group were asked not to use any topical corticosteroids during the whole 6 months follow-up period. However, this was assumed to be unacceptable for ethical reasons, as the effect of PDT could not be predicted. Ten weeks of abstinence from any topical treatment was regarded as the longest acceptable period, including a wash-out period. As it turned out, only one of the patients in the PDT group reported use of topical corticosteroids during the 6 weeks of instructed topical corticosteroid abstinence. 


\section{SUMMARY OF RESULTS}

\section{PAPER I}

In the 58 women with GELP, the median age at the time of symptom start was 51 years (range 17-78 years), with 15 women (26\%) being younger than 40 years old. Sexual abstinence was reported by 36 women and dyspareunia by another 10 . On clinical examination, vaginal involvement was seen in 49 women, including vaginal synechiae in 29 and total obliteration of the vagina in nine. Of 56 women treated with topical corticosteroids for at least three months, two had complete response and 36 partial responses, as evaluated by the doctor. Similarly, of 22 women treated with tacrolimus, three had complete and six partial response. We conclude that vaginal involvement is more common in genital erosive lichen planus than previously reported.

\section{PAPER II}

$2 \mathrm{ml} \mathrm{HAL}$ gel was applied in clinically normal and affected mucosa in 12 women with GELP using two different doses (12.5 or $100 \mathrm{mg}$ ). Biopsies were taken after $30 \mathrm{~min}$ and $3 \mathrm{~h}$. The biodistribution of HAL-induced photoactive PpIX was studied using noninvasive superficial fluorescence measurements and microscopic fluorescence photometry. More PpIX was detected after application of $12.5 \mathrm{mg} \mathrm{HAL}$ than after 100 $\mathrm{mg}$, with large inter-individual variations. PplX levels after $3 \mathrm{~h}$ were overall higher than after $30 \mathrm{~min}$. PpIX fluorescence was not detected in skin distant to the genital area. In conclusion, $2 \mathrm{ml} \mathrm{HAL} 6.25 \mathrm{mg} / \mathrm{ml}$ gel applied for $3 \mathrm{~h}$ seemed adequate for HAL absorption and conversion to Pp IX in submucosal inflammatory and epithelial cells and can be used in a PDT trial of GELP.

\section{PAPER III}

Forty women, diagnosed with GELP at a specialized vulva clinic in Oslo, were randomized to either one HAL-PDT session in vulva and/or vagina $(n=20)$ or daily applications of clobetasol propionate $0.05 \%$ ointment in vulva and optional 
hydrocortisone acetate $1.0 \%$ foam in vagina for 6 weeks $(n=20)$. Three patients in the corticosteroid group withdrew after 1-3 weeks. Mean reduction in GELP scores were similar in the PDT group and the corticosteroid group; $25 \%$ vs $22 \%$ after 6 weeks $(p=0.787)$ and $35 \%$ vs $38 \%$ after 24 weeks $(p=0.801)$. Mean reduction in pain VAS scores were $38 \%$ vs $55 \%$ after 6 weeks $(p=0.286)$ and $39 \%$ vs $12 \%$ after 24 weeks $(p=0.452)$. Patients in the PDT group reported significantly less topical corticosteroid use during weeks 7-24 than those in the corticosteroid group. No major adverse events were reported. We conclude that vulvovaginal HAL-PDT seems to be a feasible, effective and safe treatment for GELP. 


\section{DISCUSSION}

\subsection{VAginal inVOLVEMENT in GELP}

In paper I, we report symptoms, clinical and histological findings and treatment in 58 women diagnosed with GELP at a vulva clinic in Oslo, Norway. Special emphasis was made on vaginal involvement and GELP's influence on sexual function. Vaginal involvement and avoidance of sexual activity was more common in patients with GELP than reported in some previous studies ${ }^{44,58,59,64}$. More than $80 \%$ of the patients had vaginal involvement, while about one third of the patients had only vaginal involvement. Thus, these results highlight the need for a thorough clinical examination, including a full vaginal inspection, preferably by gynaecologists and dermatologists, in order to provide a correct assessment of the patient's disease.

As a consequence of chronic pain and anatomical changes in GELP, sexual activity was reported by many as difficult or impossible. Information about sexual function was reported by 51 out of 58 patients. Only one third of the patients were sexually active, and of these, most reported dyspareunia. The reason for sexual abstinence was not routinely explored by the doctor. A weakness of this study was that we did not use validated questionnaire on sexual function. Other factors, such as partner's dysfunction, cannot be excluded as causes of sexual abstinence ${ }^{78}$.

All patients but two had been treated with topical high-potent corticosteroids. Of these, a majority had partial response, including two with full response, as evaluated by the examining doctor. We used these data to perform a non-inferiority analysis to design study III, although these data had several limitations due to the retrospective study design.

No vulvovaginal neoplasia was diagnosed in any of the patients with GELP. At a later follow up, one of the patients had developed VIN on the labia minora. This is similar to other case series with long observational period ${ }^{58,59}$.

Biopsies and histological examination were performed in 49 patients. Of these, $29 \%$ were diagnostic for lichen planus, while $21 \%$ were consistent with lichen planus. Similar findings have been reported in other case series ${ }^{59,73}$. The suggested diagnostic criteria for GELP, based on clinical and histopathological findings, 
published in 2013, were not available at the time of our study, but most of our patients met at least three of the diagnostic criteria.

\subsection{HAL dosage, application time ANd PpIX biodistribution}

In the biodistributional study, the lowest HAL dose applied for 3 hours was found to be adequate for HAL absorption and conversion to Pp IX in the submucosal inflammatory cells characteristic of GELP. We found no adverse effects and no systemic uptake of HAL.

The lower HAL dose of $12.5 \mathrm{mg}$ accumulated a higher PpIX fluorescence than $100 \mathrm{mg}$, in both epithelial and submucosal tissue after 3 hours. A possible explanation for this may be a saturation and inhibitory over-dosage from the highest HAL dose. The low number of biopsies available for analyses might have influenced the results. Other dose-finding HAL studies on mucosal tissue have been conducted, but only on malignant tissue, showing partly conflicting results ${ }^{120,165}$.

GELP is a T-cell-mediated inflammatory disease, and a linear lymphocyte submucosal infiltrate is characteristic for the disease ${ }^{13}$. In our study, PpIX was predominantly localized in the basal epidermal keratinocytes and in the submucosal lymphocytes, similar to the histopathological inflammatory characteristics of GELP. We therefore assume that these cells are the main targets when HAL is activated by light exposure.

The number of keratinocytes in a GELP lesion is not higher than in normal mucosa, on the contrary, if erosions are present; there is even a loss of keratinocytes. This may be one explanation why there was no significant difference between normal and affected tissue using the two fluorescence measurement methods. Other reasons may be the possible easy access to and the accumulation of PpIX in the dermal tissue, because of the thin layer of epidermal cells in the mucosa.

\subsection{Vulvovaginal PDT}

In the RCT study, 40 women were randomized to either one session HAL-PDT or daily application of topical corticosteroid for 6 weeks. At week 6 and 24, we were not able to demonstrate any significant differences in the reduction of clinical and symptomatic scores between those treated with PDT and those treated with topical 
corticosteroids, the former group reporting less use of topical corticosteroids in weeks 7-24. Beside some soreness in the first hours after PDT, adverse effects were few and mild.

The GELP scorings were done separately in the vulva and vagina, by a doctor blinded for the treatment. There were no significant differences in scores between these locations. We were not able to find any specific demographic or clinical characteristic differences related to treatment response (data not shown). Patient's own assessment of severity of weekly pain in a VAS score was used for 24 weeks. In this way both clinical and symptomatic outcome measures were assessed, and corresponded well over time.

There is no consensus about standardized outcome measures for vulval skin conditions, including GELP ${ }^{166}$. The most commonly reported outcome measures in other studies are patient-reported symptom response to therapy ${ }^{150}$. A standardized outcome measure of vulval diseases is strongly needed. This would make it possible to compare results from different treatments.

To our knowledge, this study is the first RCT focusing on GELP. There is one RCT study on genital lichen planus comparing aloe vera and placebo. However, this study does not focus specifically on erosive lesions ${ }^{149}$.

In our study, none of the patients in the PDT group withdrew from the study. This may be interpreted as supporting a positive effect of the treatment. The long term effects were also promising, as shown in figure 6.

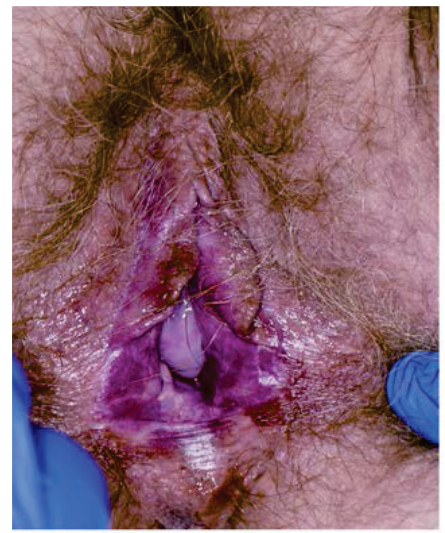

Before PDT

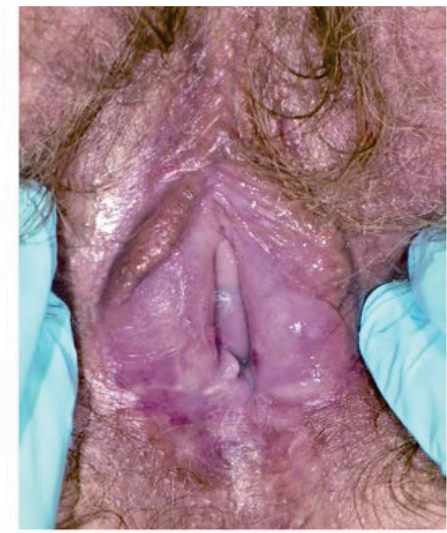

6 months after PDT

FIGURE 6. CLINICAL PHOTOGRAPHS OF THE VULVA BEFORE AND 6 MONTHS AFTER HAL-PDT IN ONE PATIENT WITH GELP 
At week 48, all but one of the patients in the PDT group stated that they would accept an offer of repeated HAL-PDT if necessary. Sixteen out of 20 patients reported overall less genital pain than before receiving PDT, and the remaining four patients reported no change. Some of the patients reported to be able to start with physical activities again, like bike cycling and having sexual intercourse.

A quantified assessment of the long-term use of topical corticosteroids can be considered as a useful tool to measure the effect and impact of a new treatment modality in GELP. In Paper III, the patient-reported use of topical corticosteroids was significantly lower in weeks 7-24 in the PDT group than in the corticosteroid group. At week 24, the number of patients reporting regular use in the PDT group was reduced to nine (from 18 pre-PDT), while the number was 15 (out of 17 patients) in the corticosteroid group. Also, the mean number of applications of topical corticosteroids per week in weeks 7-24 was reduced in the PDT group (from 2.3 times per week to less than once per week); this was not the case in the corticosteroid group (2.3 times per week both pre-study and in weeks 7-24). Taking into account the wash-out period of 4 weeks without topical corticosteroid treatment, these observations support a good symptomatic effect from vulvovaginal PDT on GELP.

During the illumination phase of the PDT procedure, many patients experienced an intense burning pain with peak intensity during the first 3-10 minutes. This is in accordance with other studies ${ }^{117,131,167,168}$ and is probably related to the initial early photo-bleaching of PpIX. The acute response immediately after illumination induced an intense erythema and oedema, mostly in the vulva. Some of the patients, however, had no soreness or discomfort after PDT and were able to leave the hospital early. Soreness while urinating in the first 1-4 days after PDT was reported by some patients. Genital candidiasis, herpes simplex infection and pruritus were only reported by patients in the corticosteroid group. 


\section{CONCLUSIONS}

These are the main conclusions from our studies:

- Vaginal involvement in GELP seems to be more frequent than described in earlier studies.

- Many women with GELP report sexual abstinence and/or dyspareunia.

- HAL seems to be a well-tolerated photosensitizer in the genital area.

- $2 \mathrm{ml} \mathrm{HAL} 6.25 \mathrm{mg} / \mathrm{ml}$ applied for 3 hours seems to be adequate for HAL absorption and conversion to Pp IX in submucosal inflammatory cells, giving no systemic absorption.

- Vulvovaginal HAL-PDT seems to be a feasible, effective and safe treatment for women with GELP, reducing the long-term need for topical corticosteroids. 


\section{FUTURE RESEARCH AND CLINICAL IMPLICATIONS}

The studies in this thesis highlight the negative impact on the quality of life for the women with GELP and the need of new treatment strategies. In the future, we would like to study the impact of GELP on the quality of life in more detail. To our knowledge, there is only published one study on this subject ${ }^{61}$. Since 2003 , we have collected data from GELP patients using validated questionnaires on sexual function (Female Sexual Distress Scale; FSDs), general health (General Health Questionnaire; GHQ 28) and the impact from having a chronic skin disease on daily life (Dermatological Quality of Life Index; DQLI).

Vulvovaginal PDT in GELP is a new treatment method that needs to be further evaluated and improved in terms of suitable photosensitizers, light sources, improved effect and less adverse effects. One important challenge is to decrease the PDTinduced pain in order to reduce the need for anaesthesiological assistance. There are at present several commercial lasers available to tighten the vaginal wall or to treat smaller parts of the vaginal mucosa. To our knowledge no specialized device exists for a complete LED light illumination of the entire vaginal wall, customized for GELP patients. Development of such a device may make vulvovaginal PDT easier to perform, possibly in an out-patients clinic.

Recognizing the anti-inflammatory effect of PDT in other skin diseases and the T-cell origin of GELP, vulvovaginal PDT is a new and promising therapeutic approach in GELP. In Paper II, we demonstrated that HAL-induced PpIX accumulation was predominantly localized in the lymphocytes in the submucosa and the keratinocytes in basal layer of the epidermal mucosa. We therefore assume that these cells are one of the targets for the cytotoxic reaction activated by light exposure. Other studies have shown that immediately after illumination, an acute PDT-induced tissue reaction with local infiltration of different inflammatory immune cells occurs in tumours ${ }^{169,170}$ ${ }^{171}$. Such initial acute inflammation may possibly trigger a specific immune response to achieve a long-term control of inflammatory diseases ${ }^{172,173}$. With biopsies available, taken from GELP lesions both pre-PDT and after 24 weeks, we will be able to analyse these biopsies by various immunohistochemical methods. Preliminary unpublished data seem to show a trend towards better clinical and symptomatic 
effect of PDT in those patients where the histopathological picture demonstrates a pronounced submucosal inflammation before treatment.

Vulvovaginal PDT may become a valuable treatment option for women with GELP, although the procedure will require specialized technical equipment and appropriate analgesics ${ }^{174}$. At the Department of Obstetrics and Gynaecology at Oslo University Hospital, PDT is now included in the regular treatment program for patients with GELP, using MAL as photosensitizer, as HAL gel is not commercially available. A LED light source has been bought for this purpose, but suitable only for external use, i.e. vulval involvement. The patients are treated as "day-care patients" at the surgery unit in a "light sedation" and are discharged from the hospital the same day. Retreatment is available at relapses.

Diseases in the vulva have been neglected by the medical profession for many years. There is great potential for improvement at all levels for the treatment of genital dermatoses, among them GELP. The establishment of specialized vulval clinics and international societies devoted to the subject of vulval disease, such as the International Society for the Study of Vulvar Disease (ISSVD) and the European College for the Study of Vulval Disease (ECSVD), has increased the medical knowledge in the field of vulval diseases. 


\section{REFERENCES}

Klapisch-Zuber C, Duby G, Perrot M. A History of women in the West : 2 : Silences of the Middle Ages. Cambridge, Mass: Belknap Press of Harvard University Press. 1992. Blackledge C. The story of V : opening Pandora's box. London: Weidenfeld \& Nicolson. 2003. Noller KL. Vulva: the forgotten pelvic organ. Obstet Gynecol 2004; 104: 913-4. Black MM, Ambros-Rudolph C, Edwards L et al. Obstetric and Gynecologic Dermatology, 3rd ed. edn. London: Elsevier Health Sciences UK. 2008.

Siddique SA. Vaginal Anatomy and Physiology. In, Vol. 9. 2003; 263-72. Paavonen J. Physiology and ecology of the vagina. Scand J Infect Dis Suppl 1983; 40: 31-5. Kumar N, Behera B, Sagiri S et al. Bacterial vaginosis: Etiology and modalities of treatment-A brief note.(Review Article)(Report). Journal of Pharmacy and Bioallied Sciences 2011; 3: 496. Stewart KMA. Vulvar Dermatoses: A Practical Approach to Evaluation and Management I Clin Outcomes Manage 2012; 12: 205-20.

Burrows LJ, Shaw HA, Goldstein AT. The vulvar dermatoses. J Sex Med 2008; 5: 276-83. Fischer GO. The commonest causes of symptomatic vulvar disease: a dermatologist's perspective. Australas J Dermatol 1996; 37: 12-8.

Bauer A, Geier J, Elsner P. Allergic contact dermatitis in patients with anogenital complaints. J Reprod Med 2000; 45: 649-54.

Foster DC. Vulvar disease. Obstet Gynecol 2002; 100: 145-63.

Wilkinson EJ, Stone IK. Atlas of vulvar disease, 2nd edn. Philadelphia: Wolters Kluwer/Lippincott Williams \& Wilkins. 2008.

Kapila S, Bradford J, Fischer G. Vulvar psoriasis in adults and children: a clinical audit of 194 cases and review of the literature. J Low Genit Tract Dis 2012; 16: 364-71.

5 Goldstein AT, Marinoff SC, Christopher K et al. Prevalence of vulvar lichen sclerosus in a general gynecology practice. J Reprod Med 2005; 50: 477-80.

Kumar V, Robbins SL, Abbas AK et al. Robbins basic pathology, 9th edn. Philadelphia, Pa: Elsevier/Saunders. 2013.

Harrington $\mathrm{Cl}$, Dunsmore IR. An investigation into the incidence of auto-immune disorders in patients with lichen sclerosus and atrophicus. Br J Dermatol 1981; 104: 563-6.

Kreuter A, Kryvosheyeva Y, Terras $\mathrm{S}$ et al. Association of autoimmune diseases with lichen sclerosus in 532 male and female patients. Acta Derm Venereol 2013; 93: 238-41.

9 Cooper SM, Ali I, Baldo $\mathrm{M}$ et al. The association of lichen sclerosus and erosive lichen planus of the vulva with autoimmune disease: a case-control study. Arch Dermatol 2008; 144: 14325. Henquet CJ. Anogenital malignancies and pre-malignancies. J Eur Acad Dermatol Venereol 2011; 25: 885-95.

Gutierrez-Pascual M, Vicente-Martin FJ, Lopez-Estebaranz JL. Lichen sclerosus and squamous cell carcinoma. Actas Dermosifiliogr 2012; 103: 21-8.

van de Nieuwenhof HP, Bulten J, Hollema $\mathrm{H}$ et al. Differentiated vulvar intraepithelial neoplasia is often found in lesions, previously diagnosed as lichen sclerosus, which have progressed to vulvar squamous cell carcinoma. Mod Pathol 2011; 24: 297-305. Lewis FM. Vulval lichen planus. Br J Dermatol 1998; 138: 569-75.

Virgili A, Levratti A, Marzola A et al. Retrospective histopathologic reevaluation of 18 cases of plasma cell vulvitis. J Reprod Med 2005; 50: 3-7. Stratton P, Turner ML, Childs R et al. Vulvovaginal chronic graft-versus-host disease with allogeneic hematopoietic stem cell transplantation. Obstet Gynecol 2007; 110: 1041-9. Riera C, Deroover Y, Marechal M. Severe vaginal chronic graft-versus-host disease (GVHD): two cases with late onset and literature review. Eur J Gynaecol Oncol 2010; 31: 703-4. 
27 Zantomio D, Grigg AP, MacGregor L et al. Female genital tract graft-versus-host disease: incidence, risk factors and recommendations for management. Bone Marrow Transplant 2006; 38: 567-72.

28 Gorouhi F, Davari P, Fazel N. Cutaneous and mucosal lichen planus: a comprehensive review of clinical subtypes, risk factors, diagnosis, and prognosis. TheScientificWorldJournal 2014; 2014: 742826.

29 Sobel JD. Desquamative inflammatory vaginitis: a new subgroup of purulent vaginitis responsive to topical 2\% clindamycin therapy. Am J Obstet Gynecol 1994; 171: 1215-20. Stockdale CK. Clinical spectrum of desquamative inflammatory vaginitis. Curr Infect Dis Rep 2010; 12: 479-83.

31 Lewis FM, Bogliatto F. Erosive vulval lichen planus--a diagnosis not to be missed: a clinical review. Eur J Obstet Gynecol Reprod Biol 2013; 171: 214-9.

32 Bohm-Starke N. Vulvar vestibulitis syndrome : pathophysiology of the vestibular mucosa. Stockholm: Karol. inst. 2001.

33 Ingafou M, Leao JC, Porter SR et al. Oral lichen planus: a retrospective study of 690 British patients. Oral Dis 2006; 12: 463-8.

34 Solomon LW, Helm TN, Stevens C et al. Clinical and immunopathologic findings in oral lichen planus pemphigoides. Oral Surg Oral Med Oral Pathol Oral Radiol Endod 2007; 103: 808-13. Lewis FM, Shah M, Harrington $\mathrm{Cl}$. Vulval involvement in lichen planus: a study of 37 women. Br J Dermatol 1996; 135: 89-91.

36 Kennedy CM, Galask RP. Erosive vulvar lichen planus: retrospective review of characteristics and outcomes in 113 patients seen in a vulvar specialty clinic. J Reprod Med 2007; 52: 43-7.

37 Silverman S, Jr., Gorsky M, Lozada-Nur F. A prospective follow-up study of 570 patients with oral lichen planus: persistence, remission, and malignant association. Oral Surg Oral Med Oral Pathol 1985; 60: 30-4.

38 Boyd AS, Neldner KH. Lichen planus. J Am Acad Dermatol 1991; 25: 593-619.

39 Eisen $\mathrm{D}$. The clinical features, malignant potential, and systemic associations of oral lichen planus: a study of 723 patients. J Am Acad Dermatol 2002; 46: 207-14.

$40 \quad$ Katta R. Lichen planus. Am Fam Physician 2000; 61: 3319-24, 27-8.

41 Eisen D. The evaluation of cutaneous, genital, scalp, nail, esophageal, and ocular involvement in patients with oral lichen planus. Oral Surg Oral Med Oral Pathol Oral Radiol Endod 1999; 88: $431-6$

42 Hunt E. LEUCOPLAKIA VULVAE, KRAUROSIS VULVAE, AND LICHEN PLANUS OF THE VULVA. Br J Dermatol 1936; 48: 53-84.

43 Scully C, el-Kom M. Lichen planus: review and update on pathogenesis. J Oral Pathol 1985; 14: 431-58.

44 Pelisse M. The vulvo-vaginal-gingival syndrome. A new form of erosive lichen planus. Int J Dermatol 1989; 28: 381-4.

45 Eisen D. The vulvovaginal-gingival syndrome of lichen planus. The clinical characteristics of 22 patients. Arch Dermatol 1994; 130: 1379-82.

46 Porter SR, Kirby A, Olsen I et al. Immunologic aspects of dermal and oral lichen planus: a review. Oral Surg Oral Med Oral Pathol Oral Radiol Endod 1997; 83: 358-66.

47 Lei L, Tan WX, Zhou XL et al. [Expression of Fas and Fas ligand in infiltrating lymphocytes in patients with oral lichen planus]. Zhonghua kou qiang yi xue za zhi = Zhonghua kouqiang yixue zazhi = Chinese journal of stomatology 2010; 45: 219-22.

48 Cooper SM, Prenter A, Allen J et al. The basement membrane zone and dermal extracellular matrix in erosive lichen planus of the vulva: an immunohistochemical study demonstrating altered expression of hemidesmosome components and anchoring fibrils. Clin Exp Dermatol 2005; 30: 277-81.

49 Scully C, Beyli M, Ferreiro MC et al. Update on oral lichen planus: etiopathogenesis and management. Crit Rev Oral Biol Med 1998; 9: 86-122. 
Asaad T, Samdani AJ. Association of lichen planus with hepatitis C virus infection. Ann Saudi Med 2005; 25: 243-6.

51 Sanchez-Perez J, De Castro M, Buezo GF et al. Lichen planus and hepatitis C virus: prevalence and clinical presentation of patients with lichen planus and hepatitis $\mathrm{C}$ virus infection. $\mathrm{Br} \mathrm{J}$ Dermatol 1996; 134: 715-9.

52 Lodi G, Giuliani M, Majorana A et al. Lichen planus and hepatitis C virus: a multicentre study of patients with oral lesions and a systematic review. Br J Dermatol 2004; 151: 1172-81.

53 Remmerbach TW, Liese J, Krause $S$ et al. No association of oral lichen planus and hepatitis C virus infection in central Germany. Clin Oral Investig 2016; 20: 193-7.

54 O'Keefe RJ, Scurry JP, Dennerstein G et al. Audit of 114 non-neoplastic vulvar biopsies. Br J Obstet Gynaecol 1995; 102: 780-6.

55 Zappi E, Zappi EA. Dermatopathology : classification of Cutaneous Lesions. Dordrecht: Springer. 2012.

56 Lever WF, Schaumburg-Lever G. Histopathology of the skin, 7th edn. Philadelphia: Lippincott. 1990.

57 Simpson RC, Littlewood SM, Cooper SM et al. Real-life experience of managing vulval erosive lichen planus: a case-based review and U.K. multicentre case note audit. Br J Dermatol 2012; 167: 85-91.

58 Cooper SM, Wojnarowska F. Influence of treatment of erosive lichen planus of the vulva on its prognosis. Arch Dermatol 2006; 142: 289-94.

59 Kirtschig G, Wakelin SH, Wojnarowska F. Mucosal vulval lichen planus: outcome, clinical and laboratory features. J Eur Acad Dermatol Venereol 2005; 19: 301-7.

60 Belfiore P, Di Fede O, Cabibi D et al. Prevalence of vulval lichen planus in a cohort of women with oral lichen planus: an interdisciplinary study. Br J Dermatol 2006; 155: 994-8.

61 Lundqvist EN, Wahlin YB, Bergdahl M et al. Psychological health in patients with genital and oral erosive lichen planus. J Eur Acad Dermatol Venereol 2006; 20: 661-6.

62 Simpson RC, Thomas KS, Leighton P et al. Diagnostic criteria for erosive lichen planus affecting the vulva: an international electronic-Delphi consensus exercise. Br J Dermatol 2013; 169: 337-43.

63 Micheletti L, Preti M, Bogliatto F et al. Vulval lichen planus in the practice of a vulval clinic. $\mathrm{Br}$ J Dermatol 2000; 143: 1349-50.

64 Ridley CM. Chronic erosive vulval disease. Clin Exp Dermatol 1990; 15: 245-52.

65 Manolache L, Seceleanu-Petrescu D, Benea V. Lichen planus patients and stressful events. J Eur Acad Dermatol Venereol 2008; 22: 437-41.

66 Fitzpatrick SG, Hirsch SA, Gordon SC. The malignant transformation of oral lichen planus and oral lichenoid lesions: a systematic review. J Am Dent Assoc 2014; 145: 45-56.

67 Moyal-Barracco M, Edwards L. Diagnosis and therapy of anogenital lichen planus. Dermatol Ther 2004; 17: 38-46.

68 Edey K, Bisson D, Kennedy C. Topical tacrolimus in the management of lichen sclerosus. BJOG 2006; 113: 1482; author reply -3.

69 Usatine RP, Tinitigan M. Diagnosis and treatment of lichen planus. Am Fam Physician 2011; 84: 53-60.

70 Lee YC, Shin SY, Kim SW et al. Intralesional injection versus mouth rinse of triamcinolone acetonide in oral lichen planus: a randomized controlled study. Otolaryngol Head Neck Surg 2013; 148: 443-9.

71 Byrd JA, Davis MD, Rogers RS, 3rd. Recalcitrant symptomatic vulvar lichen planus: response to topical tacrolimus. Arch Dermatol 2004; 140: 715-20.

72 Jensen JT, Bird M, Leclair CM. Patient satisfaction after the treatment of vulvovaginal erosive lichen planus with topical clobetasol and tacrolimus: a survey study. Am J Obstet Gynecol 2004; 190: 1759-63; discussion 63-5.

73 Bradford J, Fischer G. Management of vulvovaginal lichen planus: a new approach. J Low Genit Tract Dis 2013; 17: 28-32. 
74 McPherson T, Cooper S. Vulval lichen sclerosus and lichen planus. Dermatol Ther 2010; 23: 523-32.

75 Goldstein AT, Metz A. Vulvar lichen planus. Clin Obstet Gynecol 2005; 48: 818-23.

76 Deen K, McMeniman E. Mycophenolate mofetil in erosive genital lichen planus: a case and review of the literature. J Dermatol 2015; 42: 311-4.

77 Mann MS, Kaufman RH. Erosive lichen planus of the vulva. Clin Obstet Gynecol 1991; 34: 60513.

78 Anderson M, Kutzner S, Kaufman RH. Treatment of vulvovaginal lichen planus with vaginal hydrocortisone suppositories. Obstet Gynecol 2002; 100: 359-62.

79 Cooper SM. Vulvar lichen planus. In: UpToDate (Post TW, ed). Waltham, MA: UpToDate. 2015.

80 Cheng S, Kirtschig G, Cooper S et al. Interventions for erosive lichen planus affecting mucosal sites. The Cochrane database of systematic reviews 2012; 2: CD008092.

81 Edgardh K, Abdelnoor M. Longstanding vulval problems and entry dyspareunia among STDclinic visitors in Oslo-results from a cross-sectional study. Int J STD AIDS 2003; 14: 796-9.

82 Edgardh K. [Experiences with a special vulvar clinic in Oslo]. Tidsskr Nor Laegeforen 2005; 125: 1026-7.

83 Moan J, Peng Q. An outline of the hundred-year history of PDT. Anticancer Res 2003; 23: 3591-600.

84 Kessel D. Photodynamic therapy: from the beginning. Photodiagnosis Photodyn Ther 2004; 1: 3-7.

85 Peng $\mathrm{Q}$, Warloe T, Berg K et al. 5-Aminolevulinic acid-based photodynamic therapy. Clinical research and future challenges. Cancer 1997; 79: 2282-308.

86 Josefsen LB, Boyle RW. Photodynamic therapy: novel third-generation photosensitizers one step closer? Br J Pharmacol 2008; 154: 1-3.

87 Ericson MB, Wennberg AM, Larko $O$. Review of photodynamic therapy in actinic keratosis and basal cell carcinoma. Ther Clin Risk Manag 2008; 4: 1-9.

88 Braathen LR, Szeimies RM, Basset-Seguin N et al. Guidelines on the use of photodynamic therapy for nonmelanoma skin cancer: an international consensus. International Society for Photodynamic Therapy in Dermatology, 2005. J Am Acad Dermatol 2007; 56: 125-43.

89 Ibbotson SH. An overview of topical photodynamic therapy in dermatology. Photodiagnosis Photodyn Ther 2010; 7: 16-23.

90 Yang X, Palasuberniam P, Kraus D et al. Aminolevulinic Acid-Based Tumor Detection and Therapy: Molecular Mechanisms and Strategies for Enhancement. International journal of molecular sciences 2015; 16: 25865-80.

91 Peng $Q$, Moan J, Warloe T et al. Build-up of esterified aminolevulinic-acid-derivative-induced porphyrin fluorescence in normal mouse skin. J Photochem Photobiol B 1996; 34: 95-6.

92 Kloek J, Beijersbergen van H. Prodrugs of 5-aminolevulinic acid for photodynamic therapy. Photochem Photobiol 1996; 64: 994-1000.

93 Fotinos N, Campo MA, Popowycz F et al. 5-Aminolevulinic acid derivatives in photomedicine: Characteristics, application and perspectives. Photochem Photobiol 2006; 82: 994-1015.

94 Lange $\mathrm{N}$, Jichlinski $\mathrm{P}$, Zellweger $\mathrm{M}$ et al. Photodetection of early human bladder cancer based on the fluorescence of 5-aminolaevulinic acid hexylester-induced protoporphyrin IX: a pilot study. Br J Cancer 1999; 80: 185-93.

95 Morrow DI, McCarron PA, Woolfson AD et al. Hexyl aminolaevulinate is a more effective topical photosensitiser precursor than methyl aminolaevulinate and 5 -aminolaevulinic acids when applied in equimolar doses. J Pharm Sci 2010; 99: 3486-98.

96 Andrejevic-Blant S, Major A, Ludicke F et al. Time-dependent hexaminolaevulinate induced protoporphyrin IX distribution after topical application in patients with cervical intraepithelial neoplasia: A fluorescence microscopy study. Lasers Surg Med 2004; 35: 276-83. 
97 Togsverd-Bo K, Idorn LW, Philipsen PA et al. Protoporphyrin IX formation and photobleaching in different layers of normal human skin: methyl- and hexylaminolevulinate and different light sources. Exp Dermatol 2012; 21: 745-50.

98 Soergel $\mathrm{P}$, Wang $\mathrm{X}$, Stepp $\mathrm{H}$ et al. Photodynamic therapy of cervical intraepithelial neoplasia with hexaminolevulinate. Lasers Surg Med 2008; 40: 611-5.

99 Marti A, Jichlinski P, Lange $\mathrm{N}$ et al. Comparison of aminolevulinic acid and hexylester aminolevulinate induced protoporphyrin IX distribution in human bladder cancer. J Urol 2003; 170: 428-32.

100 Yung A, Stables GI, Fernandez C et al. Microbiological effect of photodynamic therapy (PDT) in healthy volunteers: a comparative study using methyl aminolaevulinate and hexyl aminolaevulinate cream. Clin Exp Dermatol 2007; 32: 716-21.

101 Jichlinski P, Guillou L, Karlsen SJ et al. Hexyl aminolevulinate fluorescence cystoscopy: new diagnostic tool for photodiagnosis of superficial bladder cancer--a multicenter study. J Urol 2003; 170: 226-9.

102 Berger AP, Steiner H, Stenzl A et al. Photodynamic therapy with intravesical instillation of 5aminolevulinic acid for patients with recurrent superficial bladder cancer: a single-center study. Urology 2003; 61: 338-41.

103 Wan MT, Lin JY. Current evidence and applications of photodynamic therapy in dermatology. Clin Cosmet Investig Dermatol 2014; 7: 145-63.

104 Morton CA, McKenna KE, Rhodes LE et al. Guidelines for topical photodynamic therapy: update. Br J Dermatol 2008; 159: 1245-66.

105 Valentine RM, Brown CT, Moseley $\mathrm{H}$ et al. Monte Carlo modeling of in vivo protoporphyrin IX fluorescence and singlet oxygen production during photodynamic therapy for patients presenting with superficial basal cell carcinomas. Journal of biomedical optics 2011; 16: 048002.

106 Morton CA, Brown SB, Collins S et al. Guidelines for topical photodynamic therapy: report of a workshop of the British Photodermatology Group. Br J Dermatol 2002; 146: 552-67.

107 Soler AM, Angell-Petersen E, Warloe T et al. Photodynamic therapy of superficial basal cell carcinoma with 5-aminolevulinic acid with dimethylsulfoxide and ethylendiaminetetraacetic acid: a comparison of two light sources. Photochem Photobiol 2000; 71: 724-9.

108 Christensen E, Mork C, Skogvoll E. High and sustained efficacy after two sessions of topical 5aminolaevulinic acid photodynamic therapy for basal cell carcinoma: a prospective, clinical and histological 10-year follow-up study. Br J Dermatol 2012; 166: 1342-8.

109 Tarstedt M, Gillstedt M, Wennberg Larko AM et al. Aminolevulinic acid and methyl aminolevulinate equally effective in topical photodynamic therapy for non-melanoma skin cancers. J Eur Acad Dermatol Venereol 2016; 30: 420-3.

110 Quereux G, Brocard A, Saint-Jean M et al. Photodynamic therapy with methyl-aminolevulinic acid for paucilesional mycosis fungoides: a prospective open study and review of the literature. J Am Acad Dermatol 2013; 69: 890-7.

111 Mori M, Campolmi P, Mavilia L et al. Topical photodynamic therapy for primary cutaneous Bcell lymphoma: a pilot study. J Am Acad Dermatol 2006; 54: 524-6.

112 Bhuvaneswari R, Gan YY, Soo KC et al. The effect of photodynamic therapy on tumor angiogenesis. Cell Mol Life Sci 2009; 66: 2275-83.

113 Nardelli AA, Stafinski T, Menon D. Effectiveness of photodynamic therapy for mammary and extra-mammary Paget's disease: a state of the science review. BMC Dermatol 2011; 11: 13.

114 Pech O, Behrens A, May A et al. Long-term results and risk factor analysis for recurrence after curative endoscopic therapy in 349 patients with high-grade intraepithelial neoplasia and mucosal adenocarcinoma in Barrett's oesophagus. Gut 2008; 57: 1200-6.

115 Grant WE, Hopper C, Speight PM et al. Photodynamic therapy of malignant and premalignant lesions in patients with 'field cancerization' of the oral cavity. J Laryngol Otol 1993; 107: 1140-5. 
116 Agostinis P, Berg K, Cengel KA et al. Photodynamic therapy of cancer: an update. CA Cancer J Clin 2011; 61: 250-81.

117 Daayana S, Winters U, Stern PL et al. Clinical and immunological response to photodynamic therapy in the treatment of vulval intraepithelial neoplasia. Photochemical \& photobiological sciences: Official journal of the European Photochemistry Association and the European Society for Photobiology 2011; 10: 802-9.

118 Choi MC, Kim MS, Lee GH et al. Photodynamic therapy for premalignant lesions of the vulva and vagina: A long-term follow-up study. Lasers Surg Med 2015.

119 Hillemanns P, Garcia F, Petry KU et al. A randomized study of hexaminolevulinate photodynamic therapy in patients with cervical intraepithelial neoplasia 1/2. Am J Obstet Gynecol 2015; 212: 465 e1-7.

120 Soergel P, Dahl GF, Onsrud M et al. Photodynamic therapy of cervical intraepithelial neoplasia 1-3 and human papilloma virus (HMV) infection with methylaminolevulinate and hexaminolevulinate--a double-blind, dose-finding study. Lasers Surg Med 2012; 44: 468-74.

121 Sohl S, Kauer F, Paasch U et al. Photodynamic treatment of cutaneous leishmaniasis. Journal der Deutschen Dermatologischen Gesellschaft = Journal of the German Society of Dermatology : JDDG 2007; 5: 128-30.

122 Almutawa F, Thalib L, Hekman D et al. Efficacy of localized phototherapy and photodynamic therapy for psoriasis: a systematic review and meta-analysis. Photodermatol Photoimmunol Photomed 2015; 31: 5-14.

123 Smits T, van Laarhoven Al, Staassen A et al. Induction of protoporphyrin IX by aminolaevulinic acid in actinic keratosis, psoriasis and normal skin: preferential porphyrin enrichment in differentiated cells. Br J Dermatol 2009; 160: 849-57.

124 Horfelt C, Funk J, Frohm-Nilsson M et al. Topical methyl aminolaevulinate photodynamic therapy for treatment of facial acne vulgaris: results of a randomized, controlled study. $\mathrm{Br} J$ Dermatol 2006; 155: 608-13.

125 Haedersdal M, Togsverd-Bo K, Wulf HC. Evidence-based review of lasers, light sources and photodynamic therapy in the treatment of acne vulgaris. J Eur Acad Dermatol Venereol 2008; 22: 267-78.

126 Schroeter CA, Pleunis J, van Nispen tot Pannerden C et al. Photodynamic therapy: new treatment for therapy-resistant plantar warts. Dermatol Surg 2005; 31: 71-5.

127 Fan KF, Hopper C, Speight PM et al. Photodynamic therapy using 5-aminolevulinic acid for premalignant and malignant lesions of the oral cavity. Cancer 1996; 78: 1374-83.

128 Kvaal SI, Warloe T. Photodynamic treatment of oral lesions. J Environ Pathol Toxicol Oncol 2007; 26: 127-33.

129 Aghahosseini F, Arbabi-Kalati F, Fashtami LA et al. Methylene blue-mediated photodynamic therapy: a possible alternative treatment for oral lichen planus. Lasers Surg Med 2006; 38 : 33-8.

130 Hillemanns $\mathrm{P}$, Untch $\mathrm{M}$, Prove $\mathrm{F}$ et al. Photodynamic therapy of vulvar lichen sclerosus with 5-aminolevulinic acid. Obstet Gynecol 1999; 93: 71-4.

131 Zawislak AA, McCluggage WG, Donnelly RF et al. Response of vulval lichen sclerosus and squamous hyperplasia to photodynamic treatment using sustained topical delivery of aminolevulinic acid from a novel bioadhesive patch system. Photodermatol Photoimmunol Photomed 2009; 25: 111-3.

132 Fistarol SK, Itin PH. Diagnosis and treatment of lichen sclerosus: an update. Am J Clin Dermatol 2013; 14: 27-47.

133 Kvaal SI, Angell-Petersen E, Warloe T. Photodynamic treatment of oral lichen planus. Oral surgery, oral medicine, oral pathology and oral radiology 2013; 115: 62-70.

134 Mostafa D, Tarakji B. Photodynamic therapy in treatment of oral lichen planus. J Clin Med Res 2015; 7: 393-9. 
135 Olejek A, Kozak-Darmas I, Kellas-Sleczka S et al. Effectiveness of photodynamic therapy in the treatment of lichen sclerosus: cell changes in immunohistochemistry. Neuro Endocrinol Lett 2009; 30: 547-51.

136 Kalka K, Merk H, Mukhtar H. Photodynamic therapy in dermatology. J Am Acad Dermatol 2000; 42: 389-413; quiz 4-6.

137 Kennedy JC, Pottier RH. Endogenous protoporphyrin IX, a clinically useful photosensitizer for photodynamic therapy. J Photochem Photobiol B 1992; 14: 275-92.

138 Hillemanns $\mathrm{P}$, Petry KU, Soergel P et al. Efficacy and safety of hexaminolevulinate photodynamic therapy in patients with low-grade cervical intraepithelial neoplasia. Lasers Surg Med 2014; 46: 456-61.

139 Fehr MK, Hornung R, Schwarz VA et al. Photodynamic therapy of vulvar intraepithelial neoplasia III using topically applied 5-aminolevulinic acid. Gynecol Oncol 2001; 80: 62-6.

140 Kooistra B, Dijkman B, Einhorn TA et al. How to design a good case series. J Bone Joint Surg Am 2009; 91 Suppl 3: 21-6.

141 Vandenbroucke JP. In defense of case reports and case series. Ann Intern Med 2001; 134: 330-4.

142 Edgardh K. [Vulvovaginal lichen planus--diagnosis and treatment]. Tidsskr Nor Laegeforen 2003; 123: 618-20.

143 Carey TS, Boden SD. A critical guide to case series reports. Spine 2003; 28: 1631-4.

144 Pottier RH, Chow YF, LaPlante JP et al. Non-invasive technique for obtaining fluorescence excitation and emission spectra in vivo. Photochem Photobiol 1986; 44: 679-87.

145 Angell-Petersen $\mathrm{E}$, Sorensen $\mathrm{R}$, Warloe $\mathrm{T}$ et al. Porphyrin formation in actinic keratosis and basal cell carcinoma after topical application of methyl 5-aminolevulinate. J Invest Dermatol 2006; 126: 265-71.

146 Peng Q, Soler AM, Warloe T et al. Selective distribution of porphyrins in skin thick basal cell carcinoma after topical application of methyl 5-aminolevulinate. J Photochem Photobiol B 2001; 62: 140-5.

147 Mager SR, Oomen MH, Morente MM et al. Standard operating procedure for the collection of fresh frozen tissue samples. Eur J Cancer 2007; 43: 828-34.

148 Evans D. Hierarchy of evidence: a framework for ranking evidence evaluating healthcare interventions. J Clin Nurs 2003; 12: 77-84.

149 Rajar UD, Majeed R, Parveen $\mathrm{N}$ et al. Efficacy of aloe vera gel in the treatment of vulval lichen planus. J Coll Physicians Surg Pak 2008; 18: 612-4.

150 Simpson RC, Thomas KS, Murphy R. Outcome measures for vulval skin conditions: a systematic review of randomized controlled trials. Br J Dermatol 2013; 169: 494-501.

151 Chaplan SR, Bach FW, Pogrel JW et al. Quantitative assessment of tactile allodynia in the rat paw. J Neurosci Methods 1994; 53: 55-63.

152 Grone E, Crispin A, Fleckenstein J et al. Test order of quantitative sensory testing facilitates mechanical hyperalgesia in healthy volunteers. J Pain 2012; 13: 73-80.

153 Donders GG, Bellen G. Assessing severity of pain in women with focal provoked vulvodynia: are von Frey filaments suitable devices? J Reprod Med 2014; 59: 134-8.

154 Halldin CB, Gillstedt M, Paoli J et al. Predictors of pain associated with photodynamic therapy: a retrospective study of 658 treatments. Acta Derm Venereol 2011; 91: 545-51.

155 Hillemanns P, Korell M, Schmitt-Sody M et al. Photodynamic therapy in women with cervical intraepithelial neoplasia using topically applied 5-aminolevulinic acid. Int J Cancer 1999; 81: 34-8.

156 D'Agostino RB, Sr., Massaro JM, Sullivan LM. Non-inferiority trials: design concepts and issues - the encounters of academic consultants in statistics. Stat Med 2003; 22: 169-86.

157 Snapinn SM. Noninferiority trials. Curr Control Trials Cardiovasc Med 2000; 1: 19-21.

158 Walker N, Howe C, Bullen C et al. Study protocol for a non-inferiority trial of cytisine versus nicotine replacement therapy in people motivated to stop smoking. BMC Public Health 2011; 11: 880 . 
159 Zakrzewska JM, Chan ES, Thornhill MH. A systematic review of placebo-controlled randomized clinical trials of treatments used in oral lichen planus. Br J Dermatol 2005; 153: 336-41.

160 Santegoets LA, Helmerhorst TJ, van der Meijden WI. A retrospective study of 95 women with a clinical diagnosis of genital lichen planus. J Low Genit Tract Dis 2010; 14: 323-8.

161 Helgesen AL, Gjersvik $\mathrm{P}$, Jebsen $\mathrm{P}$ et al. Vaginal involvement in genital erosive lichen planus. Acta Obstet Gynecol Scand 2010; 89: 966-70.

162 Lesaffre E. Superiority, equivalence, and non-inferiority trials. Bull NYU Hosp Jt Dis 2008; 66: 150-4.

163 Committee for Proprietary Medicinal P. Points to consider on switching between superiority and non-inferiority. Br J Clin Pharmacol 2001; 52: 223-8.

164 Gupta SK. Intention-to-treat concept: A review. Perspect Clin Res 2011; 2: 109-12.

165 Hillemanns $\mathrm{P}$, Wang $\mathrm{X}$, Hertel $\mathrm{H}$ et al. Pharmacokinetics and selectivity of porphyrin synthesis after topical application of hexaminolevulinate in patients with cervical intraepithelial neoplasia. Am J Obstet Gynecol 2008; 198: 300 e1-7.

166 Simpson RC, Murphy R. Considerations for disease impact and outcome measures in vulvar disease. J Low Genit Tract Dis 2012; 16: 460-3.

167 Hillemanns P, Untch M, Dannecker $C$ et al. Photodynamic therapy of vulvar intraepithelial neoplasia using 5-aminolevulinic acid. Int J Cancer 2000; 85: 649-53.

168 Warren CB, Karai LJ, Vidimos A et al. Pain associated with aminolevulinic acid-photodynamic therapy of skin disease. J Am Acad Dermatol 2009; 61: 1033-43.

169 Cecic I, Parkins CS, Korbelik M. Induction of systemic neutrophil response in mice by photodynamic therapy of solid tumors. Photochem Photobiol 2001; 74: 712-20.

170 Gollnick SO, Evans SS, Baumann $\mathrm{H}$ et al. Role of cytokines in photodynamic therapy-induced local and systemic inflammation. Br J Cancer 2003; 88: 1772-9.

171 Allison RR, Moghissi K. Photodynamic Therapy (PDT): PDT Mechanisms. Clinical endoscopy 2013; 46: 24-9.

172 Edstrom DW, Porwit A, Ros AM. Photodynamic therapy with topical 5-aminolevulinic acid for mycosis fungoides: clinical and histological response. Acta Derm Venereol 2001; 81: 184-8.

173 Hayami J, Okamoto $\mathrm{H}$, Sugihara A et al. Immunosuppressive effects of photodynamic therapy by topical aminolevulinic acid. J Dermatol 2007; 34: 320-7.

174 Wennberg AM. Vulvovaginal photodynamic therapy for genital erosive lichen planus. $\mathrm{Br} J$ Dermatol 2015; 173: 1119-20. 


\section{ERRATA}

\section{Paper II:}

In the second paragraph of the discussion, please change from:

In our study, such measurements showed significant differences between normal and affected mucosa, and in patients using different concentrations of HAL.

to:

In our study, such measurements showed no significant differences between normal and affected mucosa, or in patients using different concentrations of HAL. 